\title{
Polymerization and Oxidation of Alpha-1-Antitrypsin in Pathogenesis of Emphysema
}

\author{
Aleksandra Topic ${ }^{1}$ and Dragica Radojkovic ${ }^{2}$ \\ 1 University of Belgrade, Faculty of Pharmacy, Department of Medical Biochemistry, \\ 2University of Belgrade, Institute of Molecular Genetics and Genetic Enginieering, \\ Belgrade \\ Serbia
}

\section{Introduction}

The last two decades efforts have been made in investigation of genes that encode proteins involved in pathogenesis of emphysema and chronic obstructive pulmonary disease (COPD). So far, SERPINA1 gene which encodes protein alpha-1-antitrypsin (A1AT) is the only defined genetic risk factor associated with early development of emphysema.

The A1AT is dominant protein of $\alpha_{1}$ electrophoretic fraction of serum proteins, whose main physiological role is to inhibit neutrophil elastase (NE) in the lower respiratory tract, and protect pulmonary connective tissue from NE released from triggered neutrophiles. Neutrophil elastase is serine protease that degrades elastin of the alveolar walls as well other structural proteins of a variety of tissues.

Hereditary alpha-1-antitrypsin deficiency (A1ATD) is associated with retention of mutant A1AT polymers in hepatocytes which leads to decrease of circulating A1AT with less than $15 \%$ of normal level in A1ATD homozygotes. Since the integrity of lung alveoli is maintained by proper circulating level of A1AT, severe deficiency of this protein was identified as genetic risk factor for emphysema and COPD. Clinical manifestation of emphysema in patients with A1ATD occurs in 3th decade in smokers and in the 5th decade in non-smokers (Larsson, 1978; Janus et al., 1985) and requires replacement therapy with purified A1AT pooled from donor plasma.

Genetic epidemiologic studies show that A1ATD may affect 1 in about 1,500 individuals in Europe (De Serres, 2002). Approximately 3.4 million individuals of all racial subgroups are affected by A1ATD worldwide (De Serres, 2002).

Liver disease in early childhood is second clinically significant consequence resulting from retention of mutant A1AT polymers in hepatocytes (Eriksson, 1986; Sveger, 1976). Clinically it is presents as neonatal cholestasis which may progress to juvenile chirosis or slowly progress to the liver disease in adults (Mahadeva and Lomas, 1998).

In the early sixties of the last century, Laurell and Eriksson discovered that the absence of the electrophoretic $\alpha_{1}$-globulin pattern of serum is associated with A1AT deficiency (Laurell and Eriksson, 1963). At the same time was discovered an association between A1ATD and emphysema in relatively young patients in fourth decade of life (Eriksson, 1964; Lieberman, 
1969). These observations suggested a significant role of A1ATD in pathogenesis of emphysema. The proteinase-antiproteinase hypothesis, established by Janoff (Janoff, 1985) still remains central in our understanding of the pathogenesis of lung disease. According to this hypothesis, emphysema in A1ATD arises from an imbalance of neutrophil elastase and A1AT as antielastase, which leads to inappropriate antielastase defense and the relatively excessive activity of neutrophil elastase and consequent degradation of elastin and other extracellular matrix components of the lower respiratory tract.

However, only $1 \%$ of patients with COPD are A1ATD (Lieberman, et al., 1986), indicating that A1ATD alone is not sufficient to induce emphysema (Silverman, et al., 1989). The additional factor which may induce emphysema in A1ATD is inflammation, when elastin repair mechanisms are overwhelmed by a massive attack of elastase from triggered neutrophils and cigarette smoke. Studies of the genetic and environmental factors have shown a difference in the reduction of pulmonary function in A1ATD, indicating that additional genetic factors (modifier genes) may influence the pulmonary function in A1ATD subjects (Silverman et al., 1990). Also, the single-nucleotide polymorphisms (SNPs) were identified in the six haplotypes of the SERPINA1 gene, which controls synthesis of A1AT (Chappell, et al., 2006). Several environmental factors that accelerate the onset of symptoms in A1ATD patients, such as personal and second hand exposure to tobacco smoke in childhood, respiratory infections (Mayer et al., 2006), and higher exposures to ozone (Wood et al., 2009) have been also identified.

In addition to the low circulating levels of A1AT in hereditary A1ATD, the risk of emphysema includes reduced antielastase activity. Functional inactivation of A1AT by oxidants present in cigarette smoke could impair antielastase defence in lower respiratory tract, and represent acquired A1AT inactivation. Furthermore, in hereditary A1ATD smoking could impair the function of A1AT both quantitatively and qualitatively.

\section{Alpha-1-antitrypsin}

Alpha-1-antitrypsine (A1AT) is the archetype of the serpin family of proteins. SERPINs (SERine Proteinase INhibitors) are the superfamily of structurally related proteins that control many physiological processes. A1AT is a highly polymorphic, acute-phase glycoprotein, synthesised in hepatocytes (Koj et al., 1978) and subsequently secreted into the plasma. Hepatic synthesis of this acute phase protein by SERPINA1 gene is under control of different cytokines, such as interleukin-1 (IL-1), tumour necrosis factors $\alpha$ (TNF $\alpha$ ) and most effectively the interleukin-6 family of cytokines (interleukin-6, leukaemia inhibitory factor, oncostatin M) (Richards and Gauldie, 1991). Besides liver, the small quantities of A1AT are produced by alveolar macrophages, circulating monocytes and intestinal, renal and lung-derived epithelial cells (Mornex et al., 1986; Carlson et al., 1988; Molmenti et al., 1993; Cichy et al., 1997; Mulgrew et al., 2004). Extra hepatic synthesis of A1AT is important in preventing tissue damage in the site of inflammation or injury. For instance, synthesis of A1AT in monocytes is up-regulated by inflammatory mediators such as IL-1 and TNFo in lung tissue (Knoell et al., 1998). Serum level of A1AT is elevated in inflammation, trauma, and pregnancy.

Healthy individuals produce $34 \mathrm{mg}$ of A1AT per kilogram of body weight per day (Jones, 1978). Normal reference interval for antigenic concentration of serum A1AT measured by nephelometry is $15-40 \mu \mathrm{M}(0.83-2.20 \mathrm{~g} / \mathrm{L})$ (ATS/ERS Statement, 2003). The threshold level of $11 \mu \mathrm{M}(0.59 \mathrm{~g} / \mathrm{L})$ provides relevant antielastase protection of lower respiratory tract (WHO Meeting, 1996.). As a relatively small protein $(52 \mathrm{kD})$, the mature A1AT is capable to diffuse into many organs. The concentration of A1AT in organs is lower than in plasma. Thus, 
Olsen et al. (Olsen et al., 1975) reported that A1AT level in a bronchoalveolar lavage fluid of non-smokers is $7 \%$ of serum level, with a higher value $(11 \%)$ in smokers. Also, total amount of A1AT in the lavage fluid of smokers was significantly greater than in non-smokers. The same authors reported about five times higher A1AT concentration in pulmonary alveolar macrophages in smokers in comparison to non-smokers. All these results suggest an increased A1AT concentration in the air spaces of the cigarette smokers.

\subsection{Structure and function of alpha-1-antitrypsin}

The mature A1AT protein is a single chain composed of 394 amino acids. The main characteristics of the protein are: Met $^{358}$ residue at the active site, isoelectric point ranging from 4.4 to 4.6 , and a total molecular weight of $52 \mathrm{kDa}$. Crystalographic analysis of the mature protein reveals that A1AT is a globular protein with tree $\mathrm{N}$ asparigynil-linked carbohydrate side chains on the external surface of the one end of the molecule (Loebermann et al., 1984). The side chains are composed of $\mathrm{N}$-acetylglukosamine, mannose, galactose and sialic acid and they are N-linked to amino acids Asn ${ }^{46}, A_{s n}^{83}$ and Asn ${ }^{247}$. These carbohidrate side chains are on the outside surface of one-half of the elongated structure. The difference in carbohydrate side chains at position of $\mathrm{Asn}^{83}$ is responsible for the two major bands of A1AT when serum focused at $\mathrm{pH} 4-4.9$ on thin-layer polyacrilamide gel. The internal structure of A1AT is highly ordered with 30 percent $\alpha$-helices and 40 percent $\beta$-pleated sheets. There are nine $\alpha$-helices $(A \rightarrow I)$ and three $\beta$-sheets $(A \rightarrow I)$.

Similar to other inhibitory serpins, A1AT is "suicide" or "single use" inhibitor that employs a unique and extensive conformational change in the process of inhibition of target proteases (Figure 1.). The hallmark of serpins is the reactive centre loop (RCL) that presents the key $\mathrm{P} 1-\mathrm{P}^{\prime} 1$ methionine-serine bond as a pseudosubstrate for the cognate proteinase, neutrophil elastase (Johnson and Travis, 1978). The reactive centre loop of A1AT is highly stressed external loop protruding from the molecule with Met ${ }^{358}-$ Ser $^{359}$ in the active center. Inhibitory process begins by docking of the serpin and the protease, and formation of Michaelis complex. Like the other inhibitory serpins, the structure of the RCL is crucial for the ability of the inhibitor to undergo a "stressed to relaxed" $(S \rightarrow R)$ conformational change. The active A1AT is in metastable or "stressed form", which is essential for inhibition of proteases. During the process of inhibition, A1AT is like mousetrap with spring-like shift from a metastable to a hyperstable state (Hunington et al., 2000; Carrell and Lomas, 2002). After the formation of Michaelis complex there are two possible different ending of the reaction. One is inactivation of protease, where serpin has undergone the $S \rightarrow R$ transition, and the protease hangs distorted at the base of the molecule. The other possibility is A1AT substrate-like behavior, where RCL forms the fourth $\beta$-sheet, providing the opportunity for the protease to escape the conformational trap, leaving active protease and inactive cleaved serpin. Thus, in vivo, A1AT can exist in: native inhibitory conformation with an exposed RCL, latent conformation with a partially inserted RCL and non-inhibitory conformation.

Non-inhibitory conformation of A1AT occurs in certain circumstances: when A1AT is in complex with neutrophil elastase, when the reactive center loop of A1AT is cleaved by nontarget proteinases, when reactive oxygen species oxidized A1AT, and when A1ATD variants form polymers.

Moreover, A1AT non-inhibitory conformations show other biological effects. For instance, oxidized A1AT and the cleaved peptide fragment of A1AT stimulate monocyte activation, and A1AT-elastase complexes and polymeric A1AT are chemotactic for neutrophils (Banda et al., 1988; Dabbagh et al., 2001; Moraga and Janciauskiene, 2000; Moraga et al., 2001). 


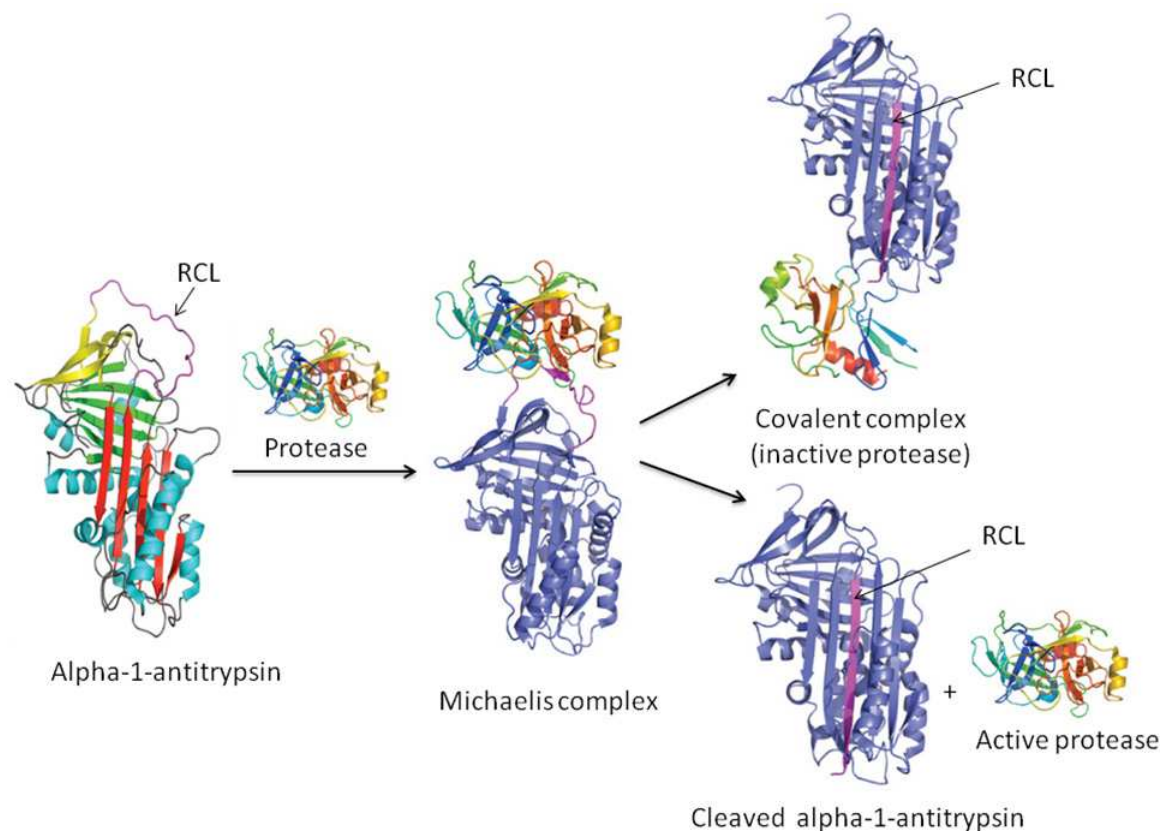

Fig. 1. Structure of alpha-1antitrypsin and reaction with target protease (modified from Law, et al., 2006)

\subsection{Physiological roles of alpha-1-antitrypsin}

The main physiological role of A1AT is protection of lower respiratory tract by inhibiting proteases released from triggered neutrophiles including neutrophil elastase, cathepsin $G$, and proteinase-3 (Carrell, 1986). The target proteases of A1AT derive from azurophilic granules of polymorphonuclear neutrophils which participate in lysosomal bacterial digestion and neutrophil migration through the extracellular matrix at the sites of inflammation. This protective role of A1AT occurs primarily extracellular. A1AT enters the lung from the circulation by passive diffusion (Stockley, 1984). Besides direct inhibition of $\mathrm{NE}$, there are evidences that A1AT exhibits anti-inflammatory properties to suppress cigarette smoke induced production of tumor necrosis factor $\alpha(\mathrm{TNF} \alpha)$ and matrix metalloproteinase 12 (MMP12) by alveolar macrophages, and subsequent inflammatory cell infiltration (Churg et al., 2007). Furthermore, studies have shown that native A1AT modulates function of immune cells, such as neutrophils (Bergin et al., 2010), monocytes (Janciauskiene et al., 2007), and T cells (Lu et al., 2006). Ex vivo and in vitro experiments have shown that endogenous A1AT in blood contributes to the suppression of proinflammatory cytokine synthesis (Pott et al., 2009). Thus, A1AT is an endogenous inhibitor of proinflammatory cytokine production in whole blood, and may participate in innate immune response to an inflammation-inducing stimulus. The recently discovered role of A1AT in prevention of emphysema is the inhibition of lung endothelial cell apoptosis due to inactivation of intracellular caspase-3 (Petrache et al., 2006a; Petrache et al., 2006b). Antiapoptotic role of A1AT in the lung in vivo and in vitro in micro vascular endothelial cells is associated with intracellular presence of A1AT. Lung endothelial cells don't produce 
A1AT and they take it. Sohrab et al. (Sohrab et al., 2009) showed that clathrin-mediated endocytosis predominantly regulates A1AT intracellular function in the lung endothelium, and might represent an important determinant of the serpin's protection against development of cigarette smoke-induced emphysema. The uptake is severely affected by exposure to cigarette smoke extract in vitro and in vivo, probably directly influencing clathrin-mediated endocytosis. Furthermore, polymers of A1AT exhibit a marked decrease in lung endothelial cell uptake. Inhibition of A1AT uptake by cigarette smoke may further weaken the A1AT protective role in the lung.

In the last decade other physiological roles of A1AT have been discovered, such as roles in atherogenesis (Talmud et al., 2003), angiogenesis (Huang et al., 2004), fibroblast proliferation, and procollagen synthesis (Dabbagh et al., 2001).

\subsection{Genetics of alpha-1-antitrypsin}

The alpha-1-antitrypsin is encoded by SERPINA1 gene (serpin peptidase inhibitor, clade A) located in proteinase inhibitor (Pi) locus on the long arm of chromosome 14q32.1 (Schroeder et al., 1985; Billingsley et al., 1993). The Pi locus is $12.2 \mathrm{~kb}$ long and consists of 4 coding exons, 3 non-coding exons and 6 introns (Figure 2.). At the $5^{\prime}$ region of the SERPINA1 gene there are three non-protein coding exons $\left(\mathrm{I}_{\mathrm{A}}, \mathrm{I}_{\mathrm{B}}, \mathrm{I}_{\mathrm{C}}\right)$ which control gene transcription. Exons referred as exons II-V are coding and containing the sequence information that defines the protein itself. The start codon (ATG) for translational of the mRNA and the signal peptide are in exon II, and the stop codon (TAA) is in exon V, followed by the polyadenilatyon signal (ATTAA). The carbohydrate attachmnent site (Asn ${ }^{46}, \mathrm{Asn}^{83}, \mathrm{Asn}{ }^{247}$ ) are coded for in exon II and III. The region coding for the reactive loop with the active inhibitory centre Met ${ }^{358}$ is within exon V.

Following transcription, A1AT mRNA is translated on ribosome bound to the the rough endoplasmatic reticulum, producing a preprotein of 418 amino acids. The signal peptide of 24 residues is removed during secretion into the cisterne of the rough endoplasmatic reticulum where the protein is glycosylated with high-mannose type carbohydrates, and folds into appropriate globular tree-dimensional configuration. Complete protein maturation is accomplished within the Golgi apparatus and protein is secreted.

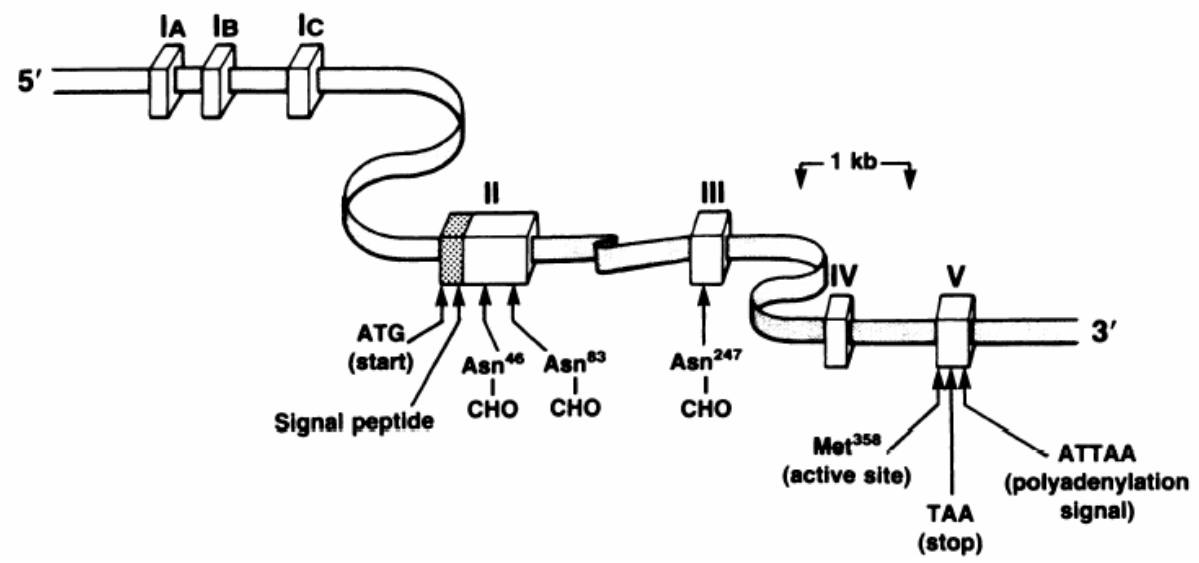

Fig. 2. Structure of the SERPINA1 gene (Crystal et al., 1989) 
Hepatocytes and monocytes have two different promotors (Perlino et al., 1987) that operate via different mechanisms. The SERPINA1 gene in macrophages is transcribed from a macrophags-specific promoter located about 2,000 bp upstream of the hepatocyte-specific promoter. Transcription from the two SERPINA1 promoters is mutually exclusive; the macrophage promoter is silent in hepatocytes, and the hepatocyte promoter is silent in macrophages. In macrophages, two distinct mRNAs are generated by alternative splicing. In addition, Hafeez et al. (Hafeez et al., 1992) demonstrated that the SERPINA1 gene has 3 monocyte-specific transcriptional initiation sites upstream from a single hepatocyte-specific transcriptional initiation site. Macrophages use these sites during basal and modulated expression. Hepatoma cells use the hepatocyte-specific transcriptional initiation site during basal and modulated expression, but also switch to transcription from the upstream macrophage transcriptional initiation sites during modulation by the acute phase mediator interleukin-6 (IL-6).

\subsection{Polymorphism of alpha-1-antitrypsin}

The A1AT coding gene SERPINA1 is a highly polimorphic, with more than 125 SNPs reported in public SNP databases (Entrez SNP). Protein variants of A1AT are classified by the Pi (Protese inhibitor) system and each variant is identified by migration on agarose gel electrophoresis. These differences in migration relate to variations in protein charge resulting from amino acid alterations (Fagerhol and Laurell, 1970; Cox, 1978). Isoelectric focusing in the narrow range of $\mathrm{pH}(4.2-4.9)$ has enabled identification of more A1AT variants then in agarose gel electrophoresis. The alleles were given symbols according to the relative electrophoretic mobility of the allele product, so anodal variants are marked with the first letters, and cathodal with last letters. All A1AT variants are categorized according to the serum level and functional activity as normal, deficient, null and dysfunctional.

\subsubsection{Normal A1AT variants}

Normal A1AT variants have normal serum level and functional activity to inhibit neutrophil elastase. More than 95\% of normal variants are the "common" M1 (Ala213), M1 (Val213), M2 and M3. Among Caucasians, M1 (Val213) is the most common, and M1 (Ala ${ }^{213}$ ), M2 and M3 are less frequent. The "rare" normal variants with frequencies less than $1 \%$ are: $\mathrm{M} 4, \mathrm{~B}_{\text {alhambra, }}$

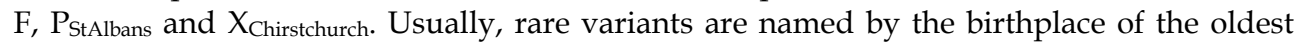
individual tested in pedegree. PiM homozygotes and heterozygotes are characterized by normal serum level of A1AT $(20-50 \mu \mathrm{M})$ and normal functional activity (ATS/ERS Statement, 2003).

\subsubsection{Deficient A1AT variants}

Deficient variants are associated with lower serum level of A1AT than normal variants. Several mutations associated with A1ATD have been identified, and the most common are $Z$ and S alleles. Rare A1ATD variants are $\mathrm{M}_{\text {Malton, }} \mathrm{M}_{\text {MineralSprings, }} \mathrm{M}_{\text {Nichinan, }} \mathrm{M}_{\text {Procida }}, \mathrm{P}_{\text {Lowell }}, \mathrm{S}_{\text {Iiyama }}$ and others.

Gene-mapping studies have shown that the PiZ allele probably arose in Northern Europe (Cox et al., 1985). Age estimates of A1AT variants based on microsatellite variation, suggest that the $Z$ deficiency allele appeared 107 to 135 generations ago and could have been spread in neolithic times. Frequency of the $\mathrm{Z}$ allele shows a large variation in Caucasians, but is rare or absent in Asians and Africans (De Croo et al., 1991; Hutchison, 1998.). 
The PiS deficiency allele has an older 279-generation to 470-generation age and from its high incidence on the Iberia peninsula it has been suggested that it could have originated in this region (Seixas et al., 2001).

\subsubsection{Z variant}

The $\mathrm{Z}$ variant represents a "classic"A1ATD variant and derives from M1 (Ala213) following a point mutation which is the same for the all $\mathrm{Z}$ individuals who are probably descendants of a single ancestral progenitor. The result of mutation is the substitution of a GAG that codes for $\mathrm{Glu}^{342}$ with an AAG that code for Lys ${ }^{342}$ (Nukiwa et al., 1987). The $\mathrm{Z}$ mutation perturbs the folding (Yu et al., 1995.) and structure of the protein (Lomas et al., 1993a). It distorts the relationship between the reactive centre loop and $\beta$-sheet $A$, and the consequent perturbation in structure allows opening of $\beta$-sheet $A$ to favor partial loop insertion and formation of an unstable intermediate $\left(\mathrm{M}^{*}\right)$ (Figure 3.). Then the patent $\beta$-sheet $\mathrm{A}$ accepts the loop of another A1AT molecule to form a dimer (D) which then extends to form chains of loop-sheet polymer (P) (Lomas, et al., 1992; Elliott et al., 1996a; Lomas, 2000).

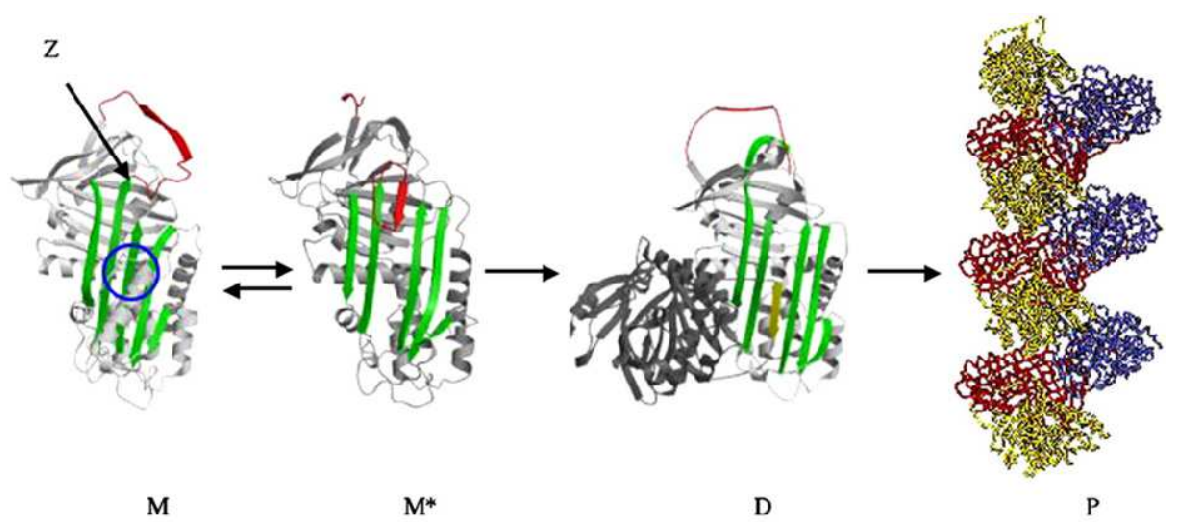

Fig. 3. Formation of $Z$ polymers (Lomas, 2005)

Process of polymerization depends on concentration and temperature. Abnormality in posttranslational modification of protein causes accumulation of the A1AT polymers in the cisterna of the rough endoplsmatic reticulum with a drastic reduction in secretion rates. The abnormal protein accumulates in hepatocytes and forms inclusion bodies (aggregates) that are positive to diastase-resistant periodic acid Schiff (PAS-D) staining and visible on microscopy. The retained A1AT polymers are cytotoxic for hepatocytes and can cause a diverse liver damages, ranging from neonatal hepatitis to juvenile cirrhosis, and hepatocellular carcinoma in adults (Eriksson, et al., 1986). As a consequence of polymer accumulation, hepatocytes of PiZZ homozygote secrete only 10-15\% of normal quantity. PiMZ heterozygotes have about $50 \%$ of normal A1AT circulating level.

Besides low circulation level, the $\mathrm{Z}$ protein also less efficiently inhibits elastase (Ogushi, et al., 1987). Consequently, in PiZZ individuals, quantitative and qualitative defects of A1AT lead to early-onset COPD including emphysema and chronic bronchitis.

A similar form of loop-sheet polymers in vivo with hepatic inclusions and plasma deficiency was found in two other variants, $\mathrm{M}_{\text {Malton }}$ (Phe ${ }^{52}$ deleted) (Lomas et al., 1995) and S Siyama (Ser53 $\rightarrow$ Phe) (Lomas et al., 1993b.), that are common in Sardinia and Japan, respectively. 
A1AT polymers were also detected in bronchoalveolar lavage fluid (BALF) from PiZ homozygotes with emphysema. This conformational transition may further reduce the levels of functional proteinase inhibitor in the lungs, and consequently exacerbate lung tissue damage (Elliott et al., 1998).

Studies of Parmar et al. (Parmar et al., 2002) and Mulgrew et al. (Mulgrew et al., 2004) showed that Z A1AT locally produced on the epithelial surface of the lung polymerizes and A1AT polymers demonstrate proapoptotic and proinflammatory effects. These studies also revealed that unlike $\mathrm{M}$ A1AT protein, $\mathrm{Z}$ A1AT protein polymerized at body temperature, and in addition of being an ineffective antiprotease inhibitor, might become a strong neutrophil chemoattractant, thus representing an ongoing source of inflammation in the lungs of individuals with A1ATD. Thus, polymerization of locally produced ZA1AT is a contributory factor to the lung inflammation experienced by those with A1AT deficiency and that standard antiprotease therapies may not address this problem. Other studies reported that even PiZZ patients with near-normal lung function had high concentrations of neutrophils on respiratory epithelial surfaces (Rouhani et al., 2000). Neutrophil burden in PiZZ and in PiMZ (on a lesser extent) is attributed to leukotriene B4 or IL-8 released from neutrophils or epithelial cells (Woolhouse et al., 2002; Malerba et al., 2006). Neutrophil accumulation in the lung of PiZZ deficient individuals is multifactorial and chemoattraction due to polymerized $\mathrm{Z}$ protein represents another potential cause of neutrophil dominated inflammation. These findings suggest a novel mechanism in pathogenesis of emphysema associated with $\mathrm{Z}$ antitrypsin deficiency.

Lomas (Lomas, 2006) highlighted a possible role of $\mathrm{Z}$ mutant in systemic response to infection. In the case of invasion of pathogens, organism initiates a systemic inflammatory response that results in increased secretion of $\mathrm{Z}$ A1AT as acute phase protein, by hepatocytes. Factors such as: elevation of body temperature, increased concentration of mutant Z A1AT, and lower $\mathrm{pH}$ at the site of bacterial invasion of lung (Stockley and Burnett, 1979) favor polymerization of mutant Z A1AT. Polymers possess chemotactic properties, which in turn amplify inflammatory response and enhance the recruitment of neutrophils. Excessive burden of neutrophils may cause increase of proinflamatory and proxidative factors.

Therefore, a rational approach in therapy of A1ATD would be to inhibit the polymerization of the $\mathrm{Z}$ protein (intracellularly and extracellularly), accompanied by standard augmentation therapy. It is clear that in addition to increased level of A1AT above a putative therapeutic threshold, it is necessary to increase the secretion of active nonpolymerized form of $Z$ protein. This approach could potentially ameliorate the liver disease, and defend respiratory epithelial surface, providing antielastase protection and avoiding the proinflammatory effects of polymerized Z A1AT.

Currently, there is some progress in development of synthetic peptide designed to selectively inhibit $\mathrm{Z}$ polymerisation (Mahadeva et al., 2002; Parfrey et al., 2004; Chang et al., 2006; Mallya et al., 2007; Chang et al., 2009).

\subsubsection{S variant}

In contrast to the $\mathrm{Z}$ allele, $\mathrm{S}$ causes only mild plasma deficiency. The genetic sequence of the $\mathrm{S}$ variant derives from $\mathrm{M} 1\left(\mathrm{Val}^{213}\right)$ as a result of a mutation which cause substitution of GAA that codes for Glu264 with an GTA that codes for Val264 (Owen et al., 1976; Yoshida et al., 1977).

The single mutation of the $S$ variant leads to spontaneous polymer formation, but slower than the $\mathrm{Z}$ variant, without affecting the ability to inhibit neutrophil elastase (Elliott, et al., 
1996b; Mahadeva et al., 1999; Dafforn et al., 1999). The slower polymerization causes less retention of $S$ variant in the liver, and hence the plasma levels are $60 \%$ of the normal $\mathrm{M}$ allele. Thus, carriers of S allele (PiSS, PiSZ and PiMS) have levels of 52\%, 32\% and 75\% of normal level, respectively. Furthermore, Z A1AT forms heteropolymers with S A1AT (Mahadeva et al., 1999), which explains cases of hepatic cirrhosis in PiSZ patients (Cruz et al., 1975; Campra et al., 1973; Craig et al., 1975.). Also, PiSZ smokers are at significant risk of the development of COPD, while in nonsmoking individuals the PiSZ phenotype may confer little or no risk to develop COPD (Turino et al., 1996).

\subsubsection{Null A1AT variants}

Null variants are characterized by the modification of an important part of the gene with no detectable mRNA. Although extremely rare, they have been found in all populations. Frequencies of null variants among Caucasians are estimated to be less than $0.1 \%$. Nullallelic variants are denoted as Q0 rather than Pi. The Null mutations do not result in secreted protein or the formation of polymers. Subjects with Null mutations show significantly lower lung function values than PiSZ and PiZZ individuals, and they are at particularly high risk to develop emphysema (Cox and Levison, 1988; Fregonese et al., 2008). Early detection of Null carriers is important for preventive and therapeutic interventions.

The PiNull ${ }_{\text {Bellingham }}$ differs from the normal M1 (Val213) gene by the mutation in exon II, where the codon for Lys 217 (AAG) is altered to Stop codon (TAG) (Satoh et al., 1988). Homozygotes for PiNull Bellingham have complete absence of A1AT, and develop premature emphysema much earlier than more common PiZZ individuals (Cook et al., 1994). The Null $_{\text {isola di procida }}$ is caused by complete deletion of exons II-V of SERPINA1 gene (Takahashi and Crystal, 1990). The Null granite falls allele derives from the M1 (Ala ${ }^{213}$ ) by the deletion of a single base in exon II in the codon for $\operatorname{Tyr}^{160}$ (TAC) with deletion of the C. Consequently, there is $5^{\prime}$ frame shift of the downstream nucleotides, moving the $\mathrm{G}$ form the next codon, Val161 GTC in place of the normal Tyr ${ }^{160}$ (Holmes et al., 1989).

The Null mattawa allele is a consequence of the insertion of a single nucleotide within the coding region of exon $\mathrm{V}$, causing a $3^{\prime}$ frameshift with generation of a premature stop signal (Curiel et al., 1989).

Prins et al. (Prins et al., 2008) performed genotyping by direct sequencing of the SERPINA1 gene coding region in patients with A1AT concentrations $\leq 1.0 \mathrm{~g} / \mathrm{L}$, and this approach allowed them to discover $\mathrm{Q} 0_{\text {soest }}$ and $\mathrm{Q} 0_{\text {amersfoort }}$ null alleles.

\subsubsection{Dysfunctional variants}

Dysfunctional A1AT variants are synthesized in normal quantities, but have altered protein function. The PiPittsburgh allele is a mutation which occurs at the A1AT active site, and represents an example of a mutation responsible for altered function of the gene product. A1AT becomes a potent inhibitor of thrombin and factor XI rather than of elastase, which results in a bleeding disorder (Lewis et al., 1978; Owen et al., 1983).

\section{Hereditary alpha-1-antitrypsin deficiency and emphysema}

The risk of developing early-onset emphysema caused by hereditary A1ATD is inversely correlated with the serum A1AT level (ATS/ERS Statement, 2003). Only PiZ homozygotes with severe decreased A1AT serum level, or carriers of M-like or Null alleles are at significant risk to develop panlobular emphysema with typical dilatation or destruction of 
all lower lobules. However, the risk of COPD in PiMZ individuals is still controversial. Heterozygous, PiMZ individuals have moderately reduced serum levels A1AT, but whether they have increased risk of COPD is uncertain. Tarjan et al. (Tarjan et al., 1994) in longitudinal lung function study in heterozygous PiMZ subjects observed a decrease in elasticity and deterioration lung function parameters in comparison to those without A1ATD, which supports the concept of PiMZ phenotype being a risk factor for pulmonary emphysema development at a younger age. Dahl et al. (Dahl et al., 2002) found that PiMZ heterozygotes had a slightly greater rate of decrease in $\mathrm{FEV}_{1}$. Meta analysis by Hersh et al. (Hersh et al., 2004) has shown an increased odd of COPD in PiMZ individuals with suggestion that variability in study design and quality limits interpretation. Recent study (Sørheim et al., 2010) suggests that PiMZ individuals may be slightly more susceptible to the development of the airflow obstruction than PiMM individuals.

\subsection{Epidemiology of A1ATD}

The majority of the data regarding frequency and geographical distribution of severe A1ATD genotypes refer to the most frequent deficient variants PiZZ and PiSZ. Considering that severe A1ATD predisposes the development of emphysema that requires expensive diagnostic methods and treatment, it would be very useful to determine prevalence of severe A1ATD in every population.

The most comprehensive study that has been performed on 200,000 Swedish newborns revealed the prevalence rate of PiZZ phenotype of approximately 1 in 1,600 newborns (Sveger, 1976). Despite the lack of reliable epidemiological studies and marked differences between countries, Blanco et al. (Blanco et al., 2006) estimated numbers of individuals carrying two most common deficiency alleles, $Z$ and $S$ in Europe. Highest prevalence of the PiZZ phenotype is in the Scandinavian Peninsula, Latvia and Denmark and progressively decreases towards the South and the East of Europe. While the highest prevalence of the PiSZ is in the Iberian Peninsula and it gradually decreases towards the North, South and East of the continent. Prevalence of the moderate PiMZ is highest in the South of the Scandinavian Peninsula, Baltic Republics, Denmark and the UK, and progressively decreases towards the East, South and North of the continent. The estimated prevalence of PiZZ, PiSZ and PiMZ in European adults was 1/4727, 1/1051 and 1/36 respectively, with large variation in different countries. In this regard, it was estimated that there are 124,594 PiZZ, 560,515 PiSZ, and even 16 million PiMZ individuals in all Europe. Globally, A1ATD affects all major racial subgroups, and there are at least 116 million carriers (PiMZ and PiMS) and 3.4 million deficiency allele's combinations (PiSS, PiSZ and PiZZ) worldwide (De Serres, 2002). According to these data, frequency of the $Z$ allele is lowest in Far East Asia $(0.04 \%)$, and highest in Northern Europe $(1.53 \%)$, while the $S$ allele is lowest in Far East Asia $(0.07 \%)$, and highest in Southern Europe $(5.64 \%)$.

Although the epidemiological data indicate a large of number of A1ATD individuals worldwide, this condition is largely undiagnosed and exact prevalence of A1ATD in most population remains unknown. Owing to data from international registry of A1ATD, established in several countries, it was estimated that only $0.35 \%$ of severe A1ATD (PiZZ and PiSZ) are actually recognized (Luisetti and Seersholm, 2004). One of the reasons may be significantly delayed onset of symptoms. In 1994 Stoller at al. (Stoller et al., 1994) reported a mean interval of 7.2 years between initial symptom and first diagnosis. A decade later, a decrement in the overall diagnostics of 5.6 years was noted (Stoller et al., 2005a), which was 
attributed to the better education of physicians about recognising A1ATD. Authors concluded that despite this decrement in the overall diagnostics, underrecognition of individuals with A1ATD persisted. Under-recognition of A1ATD may be a part of a larger phenomenon of under-recognition of individuals with COPD. The second reason could be a low penetrance of the PiZ gene, so that the relationship between genotype and clinical phenotype is not strong.

There are many benefits of early detection of A1ATD, such as avoidance of exposures to cigarette smoke and air pollution in prevention of pulmonary emphysema. Also, measure of prevention is protection from pneumonia, which is frequently reported in medical history of A1ATD patients with emphysema (McElvaney et al., 1997). In A1ATD patients, pulmonary infection further increases the risk of developing emphysema. Pulmonary infection favors increasing of elastase activity with subsequent destruction of lung due to compromised antiprotease defenses, and promotion of A1AT polymers due to elevated body temperature in inflammation. In this regard, it is very important to protect lung function of A1ATD individuals trough aggressive treatment of pulmonary infections and by vaccination with pneumococcal and influenza A vaccines.

Data concerning genetic epidemiology of the rare A1ATD variants are incomplete, and therefore raise a suspicion that the prevalence of these variants might be higher than $2-4 \%$, as previously considered, due to misclassification as $\mathrm{Z}$ variant (Luisetti and Seersholm, 2004). Phenotyping by isoelectric focusing is often used to characterize $\alpha_{1}$ AT deficiency, but this method may lead to misdiagnosis (e.g., by missing null alleles). Zorzetto et al. (Zorzetto et al., 2008) sequenced exons II, III, IV, and V of subjects whose are negative for Z and S alleles, and detected even $7 \%$ rare A1ATD alleles. Moreover, Prins et al. (Prins et al., 2008) have analyzed patients with A1ATD by sequencing of exons II, III, and V of the SERPINE1 gene and reported that up to $22 \%$ of deficiency variants were missed by conventional diagnostic methods.

\subsection{Emphysema caused by A1ATD}

The main lung manifestations of severe A1ATD are emphysema and COPD (ATS/ERS Statement, 2003). In A1ATD-smokers, the first symptoms usually occur between 32 and 41 years, with considerable variability in the time of onset of symptoms (Larsson, 1978; Tobin et al., 1983).

Panlobular emphysema is dominant clinical manifestation in A1ATD patients, and affects the lower half of the lungs. Pulmonary vessels of the emphysematous lung appear fewer and smaller than normal (Stein et al., 1971). In severe A1ATD changes at the level of bronchioli such as bronchiolitis obliterans, bronchiolectasia, acute and chronic bronchiolitis and bronchiolitis with organizing pneumonia are more frequent than in emphysema without A1ATD (Theegarten et al., 1998).

First representative study that included 124 patients with A1ATD and symptomatic emphysema (Brantly et al., 1988) showed predominance of male gender, ex-smoke status, levels of $\mathrm{A} 1 \mathrm{AT} \leq 5.5 \mu \mathrm{M}(0.3 \mathrm{~g} / \mathrm{L})$, and abnormalities in a lower zone distribution. About one third of patients had pulmonary hypertension. The lung function tests were typical for emphysema: the $\mathrm{FEV}_{1}$ and $\mathrm{DL}_{\mathrm{CO}}$ were dramatically reduced, and their annual rate of decline was greater than in general population. The cumulative probability of survival of the patients indicated a significantly shortened lifespan with a mean survival of $16 \%$ at $60 \mathrm{yr}$ of age compared with $85 \%$ for normal persons. 
The largest study ever conducted has been included 1,129 patients who participated in the National Heart, Lung, and Blood Institute (NHLBI) Registry of Individuals with Severe Deficiency of A1AT (McElvaney et al., 1997). Most frequent were PiZZ (97\%), and very few PiSZ $(1 \%)$, and rare variants $(2 \%)$. Pulmonary function test results were consistent with emphysema. The pulmonary function impairment was moderate to severe, frequently associated with a bronchodilator response, but generally with preservation of the $\mathrm{PaCO}_{2}$ until the development of severe airway obstruction. Medical history of lung function revealed that initial diagnoses included asthma (in 35\% of participants), respiratory tract allergies (28\%), pneumonia (43\%), and chronic bronchitis $(36 \%)$. The most frequent symptoms in A1ATD patients were dyspnea on exertion (in $84 \%$ of participants), selfreported wheezing during respiratory tract infections $(76 \%)$, and wheezing independent of infections (65\%), usual cough (45\%), and "annual" cough in phlegm episodes (52\%). Significant number of patients who initially diagnosed as asthma had symptoms that suggest airway hyper-responsiveness such as cough and wheezing, responded to aerosol bronchodilator moderately (Eden et al., 1997). It is interesting that a subgroup of individuals in the Registry with relatively normal lung function was younger, more likely to have never smoked and more likely to have come to medical attention owing to a family history of A1ATD.

Cigarette smoking is associated with more accelerated decline of lung function and early development of emphysema in PiZZ individuals leading to a considerably reduced life expectancy (Larsson, 1978). A mortality study showed that emphysema was a major determinant of mortality in population of severe A1ATD patients (Stoller et al., 2005b). Negative impact of smoking on survival of A1ATD patients was demonstrated in two recently published studies. Tanassh et al. (Tanash et al., 2008) reported that PiZZ individuals who have never smoked and have been identified trough screening do not have an increased mortality risk in comparison to general Swedish population. Larger study which included 1,349 PiZZ individuals selected from the Swedish National AATD Registry showed that smokers with severe A1ATD had a significantly higher mortality risk than the general Swedish population (Tanash et al., 2010). The pulmonary emphysema has been more common in PiZZ smokers (78\%) than in PiZZ never smokers $(47 \%)$, and respiratory diseases have been main cause of death among PiZZ smokers (58\%).

\subsection{Laboratory diagnosis of hereditary A1ATD}

Although being one of the most prevalent and potentially severe hereditary disorders, A1ATD still remains under-recognized. Affected individuals often visit several physicians before obtaining the correct diagnosis. The main reason is generally low knowledge about A1ATD among internists and respiratory therapists (Taliercio et al., 2010). Clinically relevant A1ATD is often caused by homozygous inheritance of the $Z$ allele, but A1ATD can also be due to the combination of other rare deficient or null alleles at the Pi locus. Even moderate A1ATD in PiMZ heterozygote is associated with reduced pulmonary functions in individuals with clinically established COPD (Dahl et al., 2001).

The guidelines of the American Thoracic Society and the European Respiratory Society (ATS/ERS Statement, 2003) recommend quantitative and qualitative laboratory testing for A1ATD for all patients with COPD, asthma, unexplained liver disease, and necrotizing panniculitis, as well as for asymptomatic subjects with persistent airflow limitation and siblings of A1ATD individuals. Laboratory testing of suspected A1ATD individuals involve 
analysis of A1AT concentrations in serum and identification of specific alleles by genotyping or phenotyping. Therefore it is important to identify appropriate cutoff that balances costs of testing identification of deficiency alleles in the general population.

Diagnostic algorithms for laboratory testing of the A1AT deficiency that were proposed (Snyder et al., 2006; Bornhorst et al., 2007; Miravitlles et al., 2010) should lead to improve diagnostics of A1ATD (Figure 4.). Initial testing involves quantification of A1AT concentrations and genotyping. Quantification of A1AT alone is not sufficient to diagnose genetic causes of A1ATD due to secondary causes of reduced concentration of A1AT in severe liver diseases, protein-losing enteropathies or nephrotic syndrome which may cause a general decrease of serum proteins. If serum level of A1AT lay in the expected range for the certain genotype, than the results and interpretation should be reported to physician. Qualitative analyses of A1ATD include two complementary methods, genotyping and phenotyping, each with advantages and disadvantages. Using conventional phenotyping of the A1AT by isoelectic focusing (IEF) necessarily leads to misdiagnoses of the null alleles (Klaassen et al., 2001). Therefore, the replacement of IEF with direct sequencing of the relevant parts of the SERPINA1 gene enables an efficient and reliable approach to reveal A1ATD patient. Direct sequencing of exons II, III and V of the SERPINA1 gene is the preferred method in initial phase of diagnostic algorithm for laboratory testing of A1ATD (Prins et al., 2008), as it allows detection of disease-associated A1AT allele combinations, including null alleles.

However if quantitative result are in discrepancy with obtained genotype, laboratory should perform phenotype assay. Determination of phenotypes serve as complementary to the genetic assay, in order to clarify cases that cannot be detected by genotyping. Besides phenotyping, other techniques that can be considered as complementary include wholegene sequencing and the addition of other alleles to the melting curve genotype assay (Rodriguez et al., 2002).

There are two approaches to assess the complementarity between serum level of A1AT and genotype result. Previously, the estimate was based on established threshold of A1AT serum levels for the most frequent A1AT phenotypes/genotypes in the general population. The various ranges for A1AT serum level of the most common phenotypes, which can be found in the literature, are results of different methods of quantification, different commercially available standards of A1AT, and samples size. (Brantly et al., 1991; Lee et al., 2002; ATS/ERS Statement, 2003). Additional difficulty is the estimation of the ranges for rare phenotypes because it is difficult to collect a representative number of samples in a given population.

In the context of these concerns, particular problem is the presence of inflammation in examined population. The A1AT is an acute phase protein and its production and secretion increases with inflammation. Thus, serum levels might be "falsely elevated" and are not reflecting the genotype, especially in moderate A1ATD. This was confirmed in a recent study which found that PiMZ individuals with a higher level of C-reactive protein (CRP, a sensitive marker of inflammation) had higher level of A1AT than those with lower level of CRP (Zorzetto et al., 2008). Also, we should bear in mind that in healthy blood donors only $26 \%$ of the variance of circulating A1AT level is explained by known SERPINA1 gene variants (Oakeshott et al., 1985). Recently, large population-based study on the Swiss SAPALDIA cohort (Senn et al., 2008) revealed that female gender, hormone intake, systolic blood pressure, age in men and in postmenopausal women, as well active and passive smoking were positively, whereas alcohol intake and body mass index (BMI) were 
inversely correlated with serum A1AT levels, independent of CRP adjustment. The results of this study reflect a complexity of relationship between tobacco exposures, gender, circulating A1AT, systemic inflammatory status and lung function.

Nowadays, the efforts are directed towards determination of the cut-off values with high specificity and sensitivity, in order to separate normal from deficient phenotypes. The value of A1AT serum level of $22 \mu \mathrm{M}(1,2 \mathrm{~g} / \mathrm{L})$ has been determined as a reliable cut-off able to identify A1ATD with a specificity of $73 \%$ and a sensitivity of $97 \%$ (Corda et al., 2006). The lower value of $18.5 \mu \mathrm{M}(1.00 \mathrm{~g} / \mathrm{L})$ was able to detect heterozygous A1ATD (Simsek et al., 2011), while cut-off value of $14.7 \mu \mathrm{M}(0.8 \mathrm{~g} / \mathrm{L})$ was proposed for detection of all patients who are at risk of A1ATD (Prins et al., 2008).

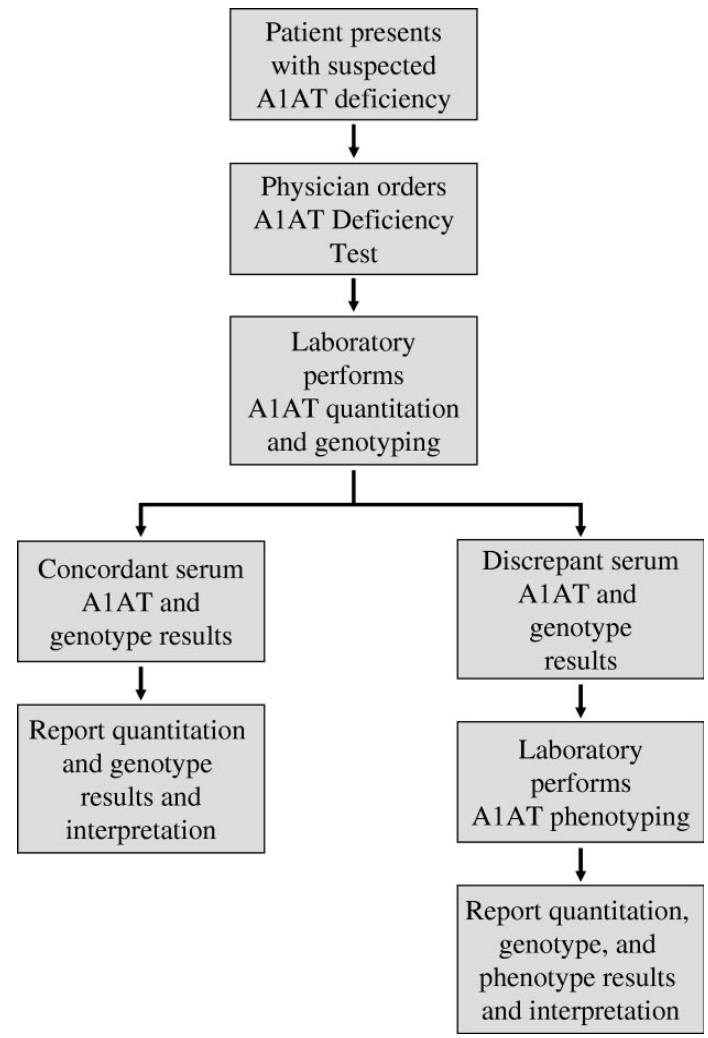

Fig. 4. Alpha-1-antitrypsin deficiency-testing algorithm (Snyder et al., 2006)

\section{Oxidation of alpha-1-antitrypsin and emphysema}

Cigarette smoke and lung inflammation leads to proteolytic destruction of the lung parenchyma with characteristic loss of alveolar integrity and an enlargement of alveolar space (reviewed in: Sharafkhaneh et al., 2008). Oxidative stress, as a result of an imbalance between oxidants and antioxidants, plays a critical role in the pathogenesis of emphysema (Rahman, 2005; Janoff et al., 1983). There are two main significant sources of oxidants: 
exogenous from cigarette smoke or air pollutants and endogenous from activated neutrophils and macrophages.

Oxidative stress caused by cigarette smoke and airway inflammation together form a vicious circle. It has been shown that cigarette smoke-mediated oxidative stress induces the release of proinflammatory cytokine by activation of NF-kappaB and posttranslational modifications of histone deacetylase in macrophages (Yang et al., 2006). Chronic inflammation that persists in emphysema leads to the activation of macrophages and neutrophils (Finkelstein et al., 1995), which are a significant source of reactive oxygen species (ROS). When ROS overwhelm lung antioxidant defenses, the oxidative stress arises. Thus, cigarette smoke and activated macrophages/neutrophils represent considerable source of reactive oxygen species in emphysema.

Cigarette smoke contains free radicals with tremendous oxidative power which serve as direct damaging agents and/or precursor of the other damaging substances. The main free radicals in cigarette smoke are superoxide $\left(\mathrm{O}_{2}^{-\bullet}\right)$, hydroxyl radical $(\bullet \mathrm{OH})$, and hydrogen peroxide $\left(\mathrm{H}_{2} \mathrm{O}_{2}\right)$ (Pryor, 1997).

Harmful effects of oxidative stress are numerous: inactivation of antiproteases, disregulation of cell proliferation, induction of apoptosis, modulation the immune system, direct damages of proteins, lipids, and nucleic acids. The products of lipid peroxidation, protein oxidation, and nucleic acid oxidation have been shown in emphysema (Mohsenin, 1991; Sahin et al., 2001; Hackett et al., 2010; Torres-Ramos et al., 2009; Deslee et al., 2009; Deslee et al., 2010).

\subsection{Oxidation of A1AT - structural and functional consequences}

$\mathrm{A} 1 \mathrm{AT}$ is a protein susceptible to oxidation, and its exposure to pro-oxidative enzymes and chemicals results in their oxidation. Exposure of one A1AT molecule to oxidants results in oxidation of Met $^{358}$ and Met ${ }^{351}$ residues to methionine sulfoxide (Johnson and Travis, 1979). Oxidation of both Met ${ }^{358}$ and Met ${ }^{351}$ significantly reduces the ability of A1AT to inhibit neutrophil elastase (Beatty et al., 1980; Taggart et al., 2000). Oxidation of Cys 232 is far more likely to occur in oxidizing environments comparing with oxidation of exposed and reactive methionine residues (Griffiths et al., 2002). The structural and biological aspects of Cys ${ }^{232}$ oxidation are still unknown.

Methionine residues can be oxidized by cigarette smoke-derived oxidants (Pryor et al., 1984), produced in vivo such as peroxide, hydroxyl radicals, chloramines, hypochloride, inducible nitric oxide, and peroxynitrite (Vogt, 1995), or with mineral dust (coal, amosite asbestos, silica, or titanium dioxide) ( $\mathrm{Li}$ et al., 1997). Thus the oxidation of A1AT by cigarette smoke or free radicals in vivo could lead to a functional deficiency of A1AT and has been suggested as a mechanism contributing to the development of emphysema in non-deficient PiM individuals. Cigarette smoke-mediated oxidation of the $\mathrm{Z}$ mutant accelerates process of polymerization, which further reduces defense of lung, increases neutrophil influx into the lungs (Alam et al., 2011), and contributes to premature emphysema in PiZZ homozygotes who smoke.

It has been reported that cigarette smoke oxidize A1AT (oxyA1AT), and reduces inhibitory activity of A1AT against elastase (Janoff et al., 1979) and caspase-3 (Petrache et al., 2006a). Substantial constituents of cigarette smoke that oxidise and inactivate A1AT include hydrogen peroxyde, nitrogen dioxide, transition metals, and products of lipid peroxidation initiated by cigarette smoke (reviewed in: Evans and Pryor, 1994). Inactivation of antielastase activity of A1AT is reversible and phenolic antioxidants prevented the suppression of serum elastase-inhibition by cigarette smoke (Carp and Janoff, 1978). 
Another mechanism of A1AT oxidation is its oxidative inactivation in the microenvironment of inflammatory cells, at sites of acute or chronic inflammation. The lower airways of smokers are infiltrated with phagocitic cells. Induced neutrophils and alveolar macrophage release a spectrum of oxidants and pro-oxidative enzymes that may inactivate A1AT in their local environment. Increased release of proteases from triggered phagocytes and reduced antiprotease defense leads to damage of lung tissue (Carp and Janoff, 1980). Myeloperoxidase-dependent production of oxidants from neutrophils is increased in inflammation, and can cause significant damage of A1AT. Myeloperoxidase (MPO) is located in the azurophilic granules of the neutrophils, and plays an important role in the human immune system by killing bacteria and invading pathogen. Under certain circumstances, a MPO can be released into the extracellular space. In the presence of hydrogen peroxide and chloride ions, MPO produces hypochlorous acid $(\mathrm{HOCl})$, the major strong oxidant which reacts readily with free amino groups to form N-chloramines. In vitro studies show that MPO inactivates purified A1AT trough oxidation of two methionine residues (Matheson et al., 1979; Summers et al., 2008). Hydrogen peroxide released from macrophages in the small airways of smokers synergistically with hydrogen peroxide from tobacco may contribute to the oxidative inhibition of A1AT (Cohen and James, 1982). Moreover, A1AT oxidized by the myeloperoxidase-hydrogen peroxide system $\left(\mathrm{MPO}-\mathrm{H}_{2} \mathrm{O}_{2}\right)$, in inflammation, promotes the formation of IgA-A1AT complexes, and consequently the elastase inhibitory activity of A1AT is reduced (Scott et al., 1999).

Recent studies have shown that although oxyA1AT loses antielastase activity it gets new biological properties that may be important in the pathogenesis of certain diseases. Several studies have shown that oxyA1AT behaves as a proinflammatory stimulus. Moraga et al. (Moraga and Janciauskiene, 2000) revealed that oxyA1AT activates monocytes, which is reflected in significant elevation in monocyte chemoattractant protein-1, cytokine IL-6, and TNF $\alpha$ expression, as well in increased activity of NADPH oxidase. Furthermore, oxyA1AT by activation of pro-oxidative NADPH oxidase may promote its own formation and thereby contributes to inflammation. OxyA1AT generated in the airway interacts directly with epithelial cells to release chemokines IL-8 and MCP-1, which in turn attracts macrophages and neutrophils into the airways ( $\mathrm{Li}$ et al., 2009). The release of oxidants by these inflammatory cells could oxidize A1AT, perpetuating the cycle and potentially contributing to the pathogenesis of COPD.

\subsection{Oxidation of A1AT - clinical aspects}

Centrolobular emphysema in smokers as a clinical manifestation is strongly associated with functional deficiency caused by oxidation of A1AT. Several studies supported the mechanism by which tobacco smoke increased the risk of developing emphysema. According to this mechanism, cigarette smoke reduces protease inhibitory capacity, causing the increase of the lung vulnerability to elastolytic destruction and thereby increasing the risk for the development of emphysema (Carp et al., 1982; Janoff et al., 1983; Ogushi et al., 1991). By losing the antiprotease ability and becoming pro-inflammatory stimulus, the oxyA1AT favors the development of clinical emphysema.

OxyA1AT has a potential clinical significance in atherogenesis. Mashiba et al. (Mashiba et al., 2001) have revealed that A1AT produced and oxidized by macrophages, attaches to low density lipoprotein (LDL) in the intima of the arterial wall and contributes to the lipid accumulation in arterial wall cells in the early stage of atherogenesis. 
In addition, reduction of antielastase activity was observed in hemodialysis patients (Hashemi et al., 2009). Furthermore, Honda et al. (Honda, et al., 2009) reported that serum levels of oxyA1AT positively correlated with myeloperoxidase in patients on hemodialysis, and could represent a useful marker for the estimation of the increasing carotid intimamedia thickness. They also found that oxyA1AT might be an independent predictor of protein-energy wasting in patients on hemodialysis. Oxidized A1AT was also detected in patients with Alzheimer's disease, heart failure, and in premature rupture of the fetal membrane (Choi et al., 2002; Banfi et al., 2008; Izumi-Yoneda et al., 2009).

\subsection{Perspective of the determination of oxidized A1AT}

Determination of oxyA1AT as biomarker is not used in routine practice, although it may be useful in assessment of pulmonary emphysema risk, and other pathological conditions associated with oxidative stress and inflammation. Our knowledge of the clinical significance of oxyA1AT is still insufficient, as well the optimal quantification of oxyA1AT.

Previously used method for quantification of oxyA1AT was based on determination of elastase- (EIC) and trypsin inhibitory capacity (TIC) (Beatty et al., 1982). As oxyA1AT loses its ability to inhibit porcine elastase but retains antitrypsin activity, the increased TIC/EIC ratio correlates with degree of A1AT oxidation. Progress in oxyA1AT methodology includes development of immunochemical method (Ueda et al., 2002).

Advanced methodology of quantification of oxyA1AT should be developed as a sensitive, specific method which would be suitable for routine practice.

\section{Conclusion}

The only proven genetic risk factor in pathogenesis of emphysema is severe alpha-1antitrypsin deficiency. However, several known and unknown genetic and environmental factors contribute to the differences in the susceptibility of A1ATD individuals to develop lung disease. Among the most important are cigarette smoke and air pollutants that could provoke oxidative stress and inflammatory response.

So far, a lot of attention and efforts in A1ATD research was given to the deficient A1AT variants and A1AT polymerization, while the oxidation of A1AT protein has been generally overlooked. Non-deficient, heavy smokers may have normal serum level of A1AT, but with reduced functional activity due to functional deficiency caused by oxidation. The physiological role of oxyA1AT could be particularly important regarding growing evidence of different biological functions of A1AT that go beyond those usually linked to its antiprotease activities. Future studies will elucidate the role of A1AT oxidation in modulation of inflammation and tissue destruction which represent landmarks of emphysema, as well in modulation of augmentation therapy.

The early recognition and diagnostics of A1ATD is the most important in terms of prevention and delay of the onset of symptoms of emphysema. The optimal approach in therapy of A1ATD would be to inhibit the polymerization of the $\mathrm{Z}$ protein (intracellular and extracellular) and prevent oxidative stress, accompanied by standard augmentation therapy.

\section{Acknowledgment}

This work was supported by grants 173008 from the Ministry of Education and Science, Republic of Serbia. 


\section{References}

Alam, S., Li, Z, Janciauskiene, S. \& Mahadeva, R. (2011). Oxidation of $Z \alpha_{1}$-antitrypsin by cigarette smoke induces polymerization: a novel mechanism of early-onset emphysema. Am J Respir Cell Mol Biol 45, 261-269.

American Thoracic Society/European Respiratory Society Statement. (2003). Standards for the diagnosis and management of individuals with alpha-1 antitrypsin deficiency. Am J Respir Crit Care Med 168, 818-900.

Banda, M.J., Rice, A.G., Griffin, G.L. \& Senior, R.M. (1988). The inhibitory complex of human $\alpha_{1}$-proteinase inhibitor and human leukocyte elastase is a neutrophil chemoattractant. J Exp Med 167, 1608-1615.

Banfi, C., Brioschi, M., Barcella, S., Veglia, F., Biglioli, P., Tremoli, E. \& Agostoni, P.G. (2008). Oxidized proteins in plasma of patients with heart failure: Role in endothelial damage. Eur J Heart Fail 10, 244-251.

Beatty, K., Robertie, P, Senior, R.M. \& Travis J. (1982). Determination of oxidized alpha-1proteinase inhibitor in serum. J Lab Clin Med 100, 186-192.

Beatty, K., Bieth, J. \& Travis, J. (1980). Kinetics of association of serine proteinases with native and oxidized $\alpha$-1-proteinase inhibitor and $\alpha$-1-antichymotrypsin. J Biol Chem 255, 3931-3934.

Bergin, D.A., Reeves, E.P., Meleady, P., Henry, M., McElvaney, O.J., Carroll, T.P., Condron, C., Chotirmall, S.H., Clynes, M., O’Neill, S.J. \& McElvaney, N.G. (2010). $\alpha-1$ antitrypsin regulates human neutrophil chemotaxis induced by soluble immune complexes and IL-8. JClin Invest 120, 4236-4250.

Billingsley, G.D., Walter, M.A., Hammond, G.L. \& Cox, D.W. (1993). Physical mapping of four serpin genes: $\alpha 1$-antitrypsin, $\alpha 1$-antishymotrypsin, corticosteroid-binding globulin, and proteinC inhibitor, within a $280-\mathrm{kb}$ region on chromosome $14 \mathrm{q} 32.1$. Am J Hum Genet 52, 343-353.

Blanco, I., De Serres, F.J., Fernandez-Bustillo, E., Lara, B. \& Miravitlles, M. (2006). Estimated numbers and prevalence of $\mathrm{PI}^{*} \mathrm{~S}$ and $\mathrm{PI} Z \mathrm{Z}$ alleles of $\alpha_{1}$-antitrypsin deficiency in European countries. Eur Respir J 27, 77-84.

Bornhorst, J.A., Procter, M., Meadows, C., Ashwood, E.R. \& Mao, R. (2007). Evaluation of an integrative diagnostic algorithm for the identification of people at risk for $\alpha_{1}$ antitrypsin deficiency. Am J Clin Pathol 128, 482-490.

Brantly M.L., Paul, L.D., Miller, B.H., Falk, R.T., Wu, M. \& Crystal, R.G. (1988). Clinical features and history of the destructive lung disease associated with alpha-1antitrypsin deficiency of adults with pulmonary symptoms. Am Rev Respir Dis 138, 327-336.

Brantly, M.L., Wittes, J.T., Vogelmeier, C.F., Hubbard, R.C., Fells, G.A. \& Crystal, R.G. (1991). Use of a highly purified alpha 1-antitrypsin standard to establish ranges for the common normal and deficient alpha 1-antitrypsin phenotypes. Chest 100, 703708.

Campra, J.L., Craig, J.R., Peters, R.L. \& Reynolds, T.B. (1973). Cirrhosis aassociated with partial deficiency of alpha-1-antitrypsn in an adult. Ann Intern Med 78, 233-238.

Carlson, J. A., Rogers B.B., Sifers R.N., Hawkins H.K., Finegold M.J. \& Woo, S.L. (1988). Multiple tissues express alpha 1-antitrypsin in transgenic mice and man. J Clin Invest 82, 26-36. 
Carp, H. \& Janoff, A. (1978). Possible mechanisms of emphysema in smokers. In vitro suppression of serum elastase-inhibitory capacity by fresh cigarette smoke and its prevention by antioxidants. Am Rev Respir Dis 118, 617-621.

Carp, H. \& Janoff, A. (1980). Potential mediator of inflammation. Phagocyte-derived oxidants suppress the elastase-inhibitory capacity of alpha 1-proteinase inhibitor in vitro. J Clin Invest 66, 987-995.

Carp, H., Miller, F., Hoidal, J.R. \& Janoff, A. (1982). Potential mechanism of emphysema: alpha 1-proteinase inhibitor recovered from lungs of cigarette smokers contains oxidize ethionine and has decreased elastase inhibitory capacity. PNAS 79, 20412045.

Carrell, R.W. (1986). Alpha 1-antitrypsin: molecular pathology, leukocytes, and tissue damage. J Clin Invest 78, 1427-1431.

Carrell, R.W. \& Lomas, D.A. (2002). Alpha1-antitrypsin deficiency-a model for conformational diseases. N Engl J Med 346, 45-53.

Chang, Y.P., Mahadeva, R., Chang, W.S., Lin, S.C. \& Chu, Y.H. (2009). Small-molecule peptides inhibit Z alpha1-antitrypsin polymerization. J Cell Mol Med 13, 2304-2316.

Chang, Y.P., Mahadeva, R., Chang, W.S., Shukla, A., Dafforn, T.R. \& Chu, Y.H. (2006). Identification of a 4-mer peptide inhibitor that effectively blocks the polymerization of pathogenic Z alpha1-antitrypsin. Am J Respir Cell Mol Biol 35, 540-548.

Chappell, S., Daly, L, Morgan, K, Baranes, G.T., Rosa, J., Rabinovich, R., Millar, A., Donnelly, S.C., Keatings, V., MacNee, W., Stolk, J., Hiemstra, P., Miniati, M., O Connor, C.M. \& Kalsheker, N. (2006). Cryptic haplotypes of SERPINA1 confer susceptibility to chronic obstructive pulmonary disease. Hum Mutat 27, 103-109.

Choi, J., Malakowsky, C.A., Talent, J.T, Conrad, C.C. \& Gracy, R.W. (2002). Identification of oxidized plasma proteins in Alzheimer's disease. Biochem Biophys Res Commun 293, 1566-1570.

Churg, A., Wang, X., Wang, R.D., Meixner, S.C., Pryzdial, E.L.G. \& Wright, J.L. (2007). $\alpha_{1^{-}}$ antitrypsin suppresses TNF- $\alpha$ and MMP-12 production by cigarette smokestimulated macrophages. Am J Respir Cell Mol Biol 37, 144-151.

Cichy, J., Potempa, J. \& Travis, J. (1997). Biosynthesis of $\alpha_{1}$-proteinase inhibitor by human lung-derived epithelial cells. J Biol Chem 272, 8250-8255.

Cohen, A.B. \& James, H.L. (1982). Reduction of the elastase inhibitory capacity of alpha 1antitrypsin by peroxides in cigarette smoke: an analysis of brands and filters. Am Rev Respir Dis 126, 25-30.

Cook, L., Janus, E.D., Brenton, S., Tai, E. \& Burdon; J. (1994). Absence of alpha-1-antitrypsin (Pi Null Bellingham) and the early onset of emphysema. Aust N Z J Med 24, 263269.

Corda, L., Bertella, E., Pini, L., Pezzini, A., Medicina, D., Boni, E., Guerini, M., Trivella, S., Grassi, V. \& Tantucci, C. (2006). Diagnostic flow chart for targeted detection of alpha1-antitrypsin deficiency. Respir Med 100, 463-470.

Cox, D.W. \& Levison, H. (1988). Emphysema of early onset associated with a complete deficiency of $\alpha_{1}$ antitrypsin (null homozygotes). Am Rev Respir Dis 137, 371-375.

Cox, D.W. Genetic variation in $\alpha_{1}$ antitrypsin. (1978). Am J Hum Genet 30, 660-662.

Cox, D.W., Woo, S.L. \& Mansfield, T. (1985). DNA restriction fragments associated with $\alpha_{1}{ }^{-}$ antitrypsin indicate a single origin for deficiency allele PI Z. Nature 316, 79-81. 
Craig, J.R., Dunn, A.E. \& Peters, R.L. (1975). Cirrhosis associated with partial deficiency of alpha-1- antitrypsin: a clinical and autopsy study. Hum Pathol 6, 113-120.

Cruz, M., Molina, J.A., Pedrola, D. \& Muñoz-López, F. (1975). Cirrhosis and heterozygous $\alpha 1$-antitrypsin deficiency in a 4 year old girl. Helv Paediatr Acta 30, 501-507.

Crystal, R.G., Brantly, M.L., Hubbard, R.C., Curiel, D.T, States, D.J. \& Holmes. M.D. (1989). The $\alpha_{1}$-antitrypsin gene and its mutations. Clinical consequences and strategies for therapy. Chest 95, 196-208.

Curiel, D., Brantly, M., Curiel, E., Stier, L. \& Crystal, R.G. (1989). $\alpha_{1}$-antitrypsin deficiency caused by the $\alpha 1$-antitrypsin Null mattawa gene. An insertion mutation rendering the $\alpha_{1}$-antitrypsin gene incapable of producing $\alpha_{1}$-antitrypsin. J Clin Invest 83, 11441152.

Dabbagh, K., Laurent, G.J., Shock, A., Leoni, P., Papakrivopoulou, J. \& Chambers, R.C. (2001). $\alpha_{1}$ antitrypsin stimulates fibroblast proliferation and procollagen production and activates classical MAP kinase signalling pathways. J Cell Physiol 186, 73-81.

Dafforn, T.R., Mahadeva R., Elliott, P.R. Sivasothy, P. \& Lomas, D.A. (1999). A kinetic mechanism for the polymerization of $\alpha_{1}$-antitrypsin. J Biol Chem 274, 9548-9555.

Dahl, M., Nordestgaard, B.G., Lange P., Vestbo, J. \&Tyjærg-Hansen, A. (2001). Molecular diagnosis of intermediate and severe $\alpha_{1}$-antitrypsin deficiency: $M Z$ individuals with chronic obstructive pulmonary disease may have lower lung function than MM individuals. Clin Chem 47, 56-62.

Dahl, M.,Tybjærg-Hansen, A., Lange, P., Vestbo, J. \& Nordestgaar, B.G. (2002). Change in lung function and morbidity from chronic obstructive pulmonary disease in $\alpha_{1}{ }^{-}$ antitrypsin $M Z$ heterozygotes: a longitudinal study of the general population. Ann Intern Med 136, 270-279.

De Croo, S., Kamboh, M.I. \&Ferrell, R.E. (1991). Population genetics of alpha-1-antitrypsin polymorphism in US whites, US blacks and African blacks. Hum Hered 41, 215- 221.

De Serres, FJ. (2002). Worldwide racial and ethnic distribution of $\alpha_{1}$-antitrypsin deficiency: summary of an analysis of published genetic epidemiologic surveys. Chest 122, 1818-1829.

Deslee, G., Woods, J.C., Moore, C., Conradi, S.H., Gierada, D.S., Atkinson, J.J., Battaile, J.T., Liu, L., Patterson, G.A., Adair-Kirk, T.L., Holtzman, M.J. \& Pierce, R.A. (2009). Oxidative damage to nucleic acids in severe emphysema. Chest 135, 965-974.

Deslee, G., Adair-Kirk, T.L., Betsuyaku, T., Woods, J.C., Moore, C.H., Gierada, D.S., Conradi, S.H., Atkinson, J.J., Toennies, H.M., Battaile, J.T., Kobayashi, D.K., Patterson, G.A, Holtzman M,J. \& Pierce, R.A. (2010). Cigarette smoke induces nucleic-acid oxidation in lung fibroblasts. Am J Respir Cell Mol Biol 43, 576-584.

Eden, E., Mitchell, D., Mehlman, B., Khouli, H., Mejat, M., Grieco, M.H. \& Turino, G.M. (1997). Atopy, asthma and emphysema in patients with severe $\alpha_{1}$ antitrypsin deficiency. Am J Respir Crit Care Med 156, 68-74.

Elliott, P.R., Lomas, D.A., Carrell, R.W. \& Abrahams, J.P. (1996a). Inhibitory conformation of the reactive loop of $\alpha_{1}$-antitrypsin. Nat Struct Biol 3, 676-681.

Elliott, PR., Stein, P.E., Bilton, D., Carrell, R.W. \& Lomas, D.A. (1996b). Structural explanation for the deficiency of $S \alpha_{1}$-antitrypsin. Nat Struct Biol 3, 910-911.

Elliott, P.R., Bilton, D. \& Lomas, D.A. (1998). Lung Polymers in $Z \alpha_{1}$-antitrypsin deficiencyrelated emphysema. Am J Respir Cell Mol Biol 18, 670-674.

Entrez SNP, http:/ / www.ncbi.nlm.nih.gov/ projects/SNP. 
Eriksson, S., Carlson, J. \& Velez, R. (1986). Risk of cirrhosis and primary liver cancer in $\alpha_{1}$ antitrypsin deficiency. N Engl J Med 314, 736-739.

Eriksson, S. (1964). Pulmonary emphysema and alpha-1-antitrypsin deficiency. Acta Med Scand 175, 197-205.

Evans, M.D. \& Pryor, W.A. (1994). Cigarette smoking, emphysema, and damage to $\alpha_{1}$ proteinase inhibitor. Am J Physiol Lung Cell Mol Physiol 266, L593-L611.

Fagerhol, M.K. \& Laurell, C.B. (1970). The Pi system-inherited variants of serum $\alpha_{1}$ antitrypsin. Prog Med Genet 7, 96-111.

Finkelstein, R., Fraser, R.S., Ghezzo, H. \& Cosio, M.G. (1995). Alveolar inflammation and its relation to emphysema in smokers. Am J Respir Crit Care Med 152, 1666-1672.

Fregonese, L., Stolk, J., Frants, R.R. \& Veldhuisen, B. (2008). $\alpha_{1}$ antitrypsin Null mutations and severity of emphysema. Respir Med 102, 876-884.

Griffiths, S.W., King, J. \& Cooney, C.L. (2002). The reactivity and oxidation pathway of cysteine 232 in recombinant human $\alpha_{1}$-antitrypsin. J Biol Chem 277, 25486-25492.

Hackett, T.L., Scarci, M., Zheng, L., Tan, W., Treasure, T. \& Warner, J.A. (2010). Oxidative modification of albumin in the parenchymal lung tissue of current smokers with chronic obstructive pulmonary disease. Respir Res 11, 180.

Hafeez, W., Ciliberto, G. \& Perlmutter, D. H. (1992). Constitutive and modulated expression of the human $\alpha 1$ antitrypsin gene: different transcriptional initiation sites used in three different cell types. J Clin Invest 89, 1214-1222.

Hashemi, M., Mehrabifar, H., Homayooni, F., Naderi, M., Montazerifar, F. \& Ghavami, S. (2009). Serum trypsin inhibitory capacity in hemodialysis patients. Saudi J Kidney Dis Transpl 20, 604-607.

Hersh, C.P., Dahl, M., Ly, N.P., Berkey, C.S., Nordestgaard, B.G. \& Silverman, E.K. (2004). Chronic obstructive pulmonary disease in $\alpha_{1}$ antitrypsin PI MZ heterozygotes: meta-analysis. Thorax 59, 843-849.

Honda, H., Ueda, M., Kojima, S., Mashiba, S., Hirai, Y., Hosaka, N., Suzuki, H., Mukai, M., Watanabe, M., Takahashi, K., Shishido, K. \& Akizawa, T. (2009). Assessment of myeloperoxidase and oxidative $\alpha_{1}$-antitrypsin in patients on hemodialysis. Clin J Am Soc Nephrol 4: 142-151.

Holmes, M., Curiel, D., Brantly, M. \& Crystal, R.G. (1989). Characterization of the intracellular mechanism causing the alpha-1-antitrypsin Null granite falls deficiency state. Am Rev Respir Dis 140, 1662-1667.

Huang, H., Campbell, S.C., Nelius, T., Bedford, D.F., Veliceasa, D., Bouck, N.P. \& Volpert, O.V. (2004). Alpha1-antitrypsin inhibits angiogenesis and tumor growth. Int $J$ Cancer, 112, 1042-1048.

Hunington, J.A., Read, R.J. \& Carrell, R.W. (2000). Structure of a serpin-protease complex shows inhibition by deformation. Nature 407, 923-926.

Hutchison, D.C.S. (1998). $\alpha_{1}$-antitrypsin deficiency in Europe: geographical distributionof Pi types $\mathrm{S}$ and Z. Resp Med 92, 367-377.

Izumi-Yoneda, N., Toda, A., Okabe, M., Koike, C., Takashima, S., Yoshida, T., Konishi, I., Saito, S. \& Nikaido, T. (2009). Alpha 1 antitrypsin activity is decreased in human amnion in premature rupture of the fetal membranes. Mol Hum Reprod 15, 49-57.

Janciauskiene, S.M., Nita, I.M. \& Stevens, T. (2007). $\alpha_{1}$-antitrypsin, old dog, new tricks. $\alpha_{1}{ }^{-}$ antitrypsin exerts in vitro anti-inflammatory activity in human monocytes by elevating cAMP. J Biol Chem 282, 8573-8582. 
Janoff, A., Carp, H., Laurent, P. \& Raju. L. (1983). The role of oxidative processes in emphysema. Am Rev Respir Dis 127, S31-S38.

Janoff, A., Carp, H., Lee, D. K. \& Drew, R.T. (1979). Cigarette smoke inhalation decreases $\alpha 1-$ antitrypsin activity in rat lung. Science 206, 1313-1314.

Janoff, A. (1985). Elastases and emphysema. Current assessment of the protease-antiprotease hypothesis. Am Rev Respir Dis 132, 417-433.

Janus, E.D., Phillips, N.T. \& Carrell, R.W. (1985). Smoking, lung function and $\alpha_{1}$-antitrypsin deficiency. Lancet 1, 152-154.

Johnson, D. \& Travis, J. (1979). The oxidative inactivation of human alpha-1-proteinase inhibitor. Further evidence for methionine at the reactive center. J Biol Chem 254, 4022-4026.

Johnson, D. \& Travis, J. (1978). Structural evidence for methionine at the reactive site of human $\alpha$-1-proteinase inhibitor. J Biol Chem 253, 7142-7144.

Jones, E.A., Vergalla, J., Steer, C.J., Bradley-Moore, P.R. \& Vierling, J.M. (1978). Metabolism of intact and desialylated $\alpha_{1}$ antitrypsin. Clin Sci Mol Med 55, 139-148.

Klaassen, C.H.W., de Metz, M., van Aarssen, Y. \& Janssen, J. (2001). $\alpha_{1}$ antitrypsin deficiency as a result of compound heterozygosity for the $\mathrm{Z}$ and $\mathrm{M}_{\text {Heerlen }}$ alleles. Clin Chem 47, 978-979.

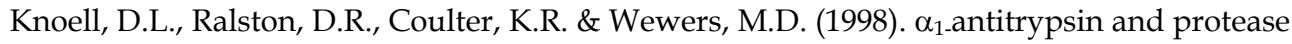
complexation is induced by lipopolysaccharide, interleukin-1 $\beta$, and tumor necrosis factor- $\alpha$ in monocytes. Am J Respir Crit Care Med., Jan 157, 246-255.

Koj, A., Regoeczi, E., Toews, C.J., Leveille, R. \& Gauldie, J. (1978). Synthesis of antithrombin III and $\alpha_{1}$ antitrypsin by the perfused rat liver. Biochim Biophys Acta 539, 496-504.

Lai, E.C., Kao, F.T., Law, M.L. \& Woo, S.L. (1983). Assignment of the $\mathrm{a}_{1}$-antitrypsin gene and a sequence-related gene to human chromosome 14 by molecular hybridization. Am J Hum Genet 35, 385-392.

Larsson, C. (1978). Natural history and life expectancy in severe $\alpha_{1}$-antitrypsin deficiency, Pi Z. Acta Med Scand 204, 345-351.

Laurell, C.B. \& Eriksson, S. (1963). The electrophoretic $\alpha_{1}$-globulin pattern of serum in $\alpha_{1}{ }^{-}$ antitrypsin deficiency. Scand J Clin Lab Invest, 15, 132-140.

Law, R.H., Zhang, Q., McGowan, S., Buckle, A.M., Silverman, G.A., Wong, W., Rosado, C.J., Langendorf, C.G, Pike, R.N., Bird, P.I. \& Whisstock, J.C. (2006). An overview of the serpin superfamily. Genome Biol 7, 216.

Lee. P., Gildea, T.R. \& Stoller, J.K. (2002). Emphysema in nonsmokers: $\alpha_{1}$-antitrypsin deficiency and other causes. Cleve Clin J Med 69, 928-946.

Lewis, J. H., Iammarino, R. M., Spero, J. A. \& Hasiba, U. (1978). Antithrombin Pittsburgh: an alpha1-antitrypsin variant causing hemorrhagic disease. Blood 51, 129-137.

Li, K., Zay, K. \& A. Churg. (1997). Mineral dusts oxidize methionine residues: probable mechanism of inactivation of alpha-1-antitrypsin. Ann Hyg 41, 379-383.

Li, Z., Alam, S., Wang, J., Sandstrom, C.S., Janciauskiene, C. \& Mahadeva, R. (2009). Oxidized $\alpha_{1}$-antitrypsin stimulates the release of monocyte chemotactic protein-1 from lung epithelial cells: potential role in emphysema. Am J Physiol Lung Cell Mol Physiol 297, L388-L400.

Lieberman, J. (1969). Heterozygous and homozygous $\alpha_{1}$-antitrypsin deficiency in patients with pulmonary emphysema. N Engl J Med 281, 279-284. 
Lieberman, J; Winter, B. \& Sastre, A. (1986). $\alpha_{1}$-antitrypsin Pi types in 956 COPD patients. Chest 89, 370-373.

Loebermann, H., Tokuoka, R., Deisenhofer, J. \& Huber, R. (1984). Human $\alpha_{1}$-proteinase inhibitor: crystal modifications, molecular model and preliminary analysis of the implications for function. J Mol Biol 177, 531-556.

Lomas, D.A. (2005). Molecular mousetraps, $\alpha_{1}$-antitrypsin deficiency and the serpinopathies. Clin Med 5, 249-257.

Lomas, D.A., Elliott, P.R., Sidhar, S.K., Foreman R.C., Finch, J.T., Cox, D.W., Whisstock, J.C. \& Carrell, R.W. (1995). $\alpha_{1}$-antitrypsin Mmalton (Phe ${ }^{52}$-deleted) forms loop-sheet polymers in vivo. Evidence for the $\mathrm{C}$ sheet mechanism of polymerization. J Biol Chem 14, 16864-16870.

Lomas, D. A., Evans, D.L., Stone, S.R., Chang, W.S. \& Carrell. R.W. (1993a). Effect of the Z mutation on the physical and inhibitory properties of $\alpha_{1}$-antitrypsin. Biochemistry 32, 500-508.

Lomas, D.A., Finch, J.T., Seyama, K., Nukiwa, T. \& Carrell, R.W. (1993b). a1-antitrypsin Siiyama (Ser ${ }^{33} \rightarrow$ Phe). Further evidence for intracellular loop-sheet polymerization. JBiolChem 268, 15333-15335.

Lomas, DA. (2000). Loop-sheet polymerization: the mechanism of $\alpha_{1}$-antitrypsin deficiency. Respir Med 94, Suppl C, S3-S6.

Lomas, D.A. (2006).The selective advantage of $\alpha_{1}$-antitrypsin deficiency. Am J Respir Crit Care Med 173, 1072-1077.

Lomas, D.A., Evans, D.L., Finch, J.J. \& Carell, R.W. (1992). The mechanism of Z $\alpha_{1}{ }^{-}$ antitrypsin accumulation in the liver. Nature 357, 605-607.

Long, G.L., Chandra, T., Woo, S.L.C., Davie, E.W. \& Kurachi, K. (1984). Complete sequence of the cDNA for human alpha-1-antitrypsin and the gene for the $\mathrm{S}$ variant. Biochemistry 23, 4828-4837.

Lu, Y., Tang, M., Wasserfall, C., Kou, Z., Campbell-Thompson, M., Gardemann, T., Crawford, J., Atkinson, M., \& Song, S. (2006). $\alpha_{1}$-antitrypsin gene therapy modulates cellular immunity and efficiently prevents type 1 diabetes in nonobese diabetic mice. Hum Gene Ther 17, 625-634.

Luisetti, M. \& Seersholm, N. (2004). $\alpha_{1}$-antitrypsin deficiency. 1: Epidemiology of $\alpha_{1}$ antitrypsin deficiency. Thorax 59, 164-169.

Mahadeva, R., Dafforn, T.R., Carrell, R.W. \& Lomas, D.A. (2002). 6-mer peptide selectively anneals to a pathogenic serpin conformation and blocks polymerization: implications for the prevention of $\mathrm{Z} \alpha_{1}$-antitrypsin -related cirrhosis. J Biol Chem 277, 6771-6774.

Mahadeva, R., Chang, W.S., Dafforn, T.R., Oakley, D.J., Foreman, R.C., Calvin, J., Wight, D.G. \& Lomas, D.A. (1999). Heteropolymerization of S, I, and $\mathrm{Z} \alpha_{1}$-antitrypsin and liver cirrhosis. J Clin Invest 103, 999-1006.

Mahadeva, R. \& Lomas, D.A. (1998). Alpha 1 -antitrypsin deficiency, cirrhosis and emphysema. Thorax 53, 501-505.

Malerba, M., Ricciardolo, F., Torregiani, C., Radaeli, A., Ceriani, L., Mori, E., Bontempelli, M., Grassi, V \& Tantucci, C. (2006). Neutrophilic inflammation and IL-8 levels in induced sputum of alpha-1-antitrypsin PiMZ subjects. Thorax 61, 129-133.

Mallya M, Phillips RL, Saldanha SA, Gooptu B, Brown SC, Termine DJ, Shirvani AM, Wu Y, Sifers, R.N., Abagyan, R. \& Lomas, D.A. (2007). Small molecules block the 
polymerization of $\mathrm{Z} \alpha_{1}$-antitrypsin and increase the clearance of intracellular aggregates. J Med Chem 50, 5357-5363.

Mashiba, S., Wada, Y., Takeya, M., Sugiyama, A., Hamakubo, T., Nakamura, A., Noguchi, N., Niki, E., Izumi, A., Kobayashi, M., Uchida, K. \& Kodama, T. (2001). In vivo complex formation of oxidized $\alpha_{1}$-antitrypsin and LDL. Arterioscler Thromb Vasc Biol 21, 1801-1808.

Matheson, N.R., Wong, P.S. \& Travis, J. (1979). Enzymatic inactivation of human alpha-1proteinase inhibitor by neutrophil myeloperoxidase. Biochem Biophys Res Commun $88,402-409$.

Mayer, A.S., Stoller, J.K., Vedal, S., Ruttenber, A.J., Strand, M., Sandhaus, R.A. \& Newman, L.S. (2006). Risk factors for symptom onset in $\mathrm{PI}^{\star} \mathrm{Z}$ alpha-1antitrypsin deficiency. Int J Chron Obstruct Pulmon Dis 1, 485-492.

McElvaney, N.G., Stoller, J.K., Buist, A.S., Prakash, U.B.S., Brantly, M.L., Schluchter, M.D. \& Crystal, R.D. (1997). Baseline characteristics of enrollees in the national heart, lung, and blood institute registry of $\alpha_{1}$-antitrypsin deficiency. Chest 111, 394-403.

Miravitlles, M., Herr, C., Ferrarotti, I., Jardi, R., Rodriguez-Frias, F., Luisetti. M. \& Bals. R. (2010). Laboratory testing of individuals with severe $\alpha_{1}$-antitrypsin deficiency in three European centres. Eur Respir J 35, 960-968.

Mohsenin, V. (1991). Lipid peroxidation and antielastase activity in the lung under oxidant stress: role of antioxidant defenses. J Appl Physiol 70, 1456-1462.

Molmenti, E. P., Perlmutter, D. H. \& Rubin, D.C. (1993). Cell-specific expression of $\alpha_{1}{ }^{-}$ antitrypsin in human intestinal epithelium. J Clin Invest 92, 2022-2034.

Moraga, F. \& Janciauskiene, S. (2000). Activation of primary human monocytes by the oxidized form of $\alpha_{1}$-antitrypsin. J Biol Chem 275, 7693-7700.

Moraga, F., Lindgren, S. \& Janciaskiene, S. (2001). Effects of noninhibitory $\alpha_{1}$-antitrypsin on primary human monocyte activation in vitro. Arch Biochem Biophys 386: 221-226.

Mornex, J.F., Chytil-Weir, A., Martinet, Y., Courtney, M., LeCocq, J.P. \& Crystal, R.G. (1986). Expression of the alpha-1-antitrypsin gene in mononuclear phagocytes of normal and alpha-1-antitrypsin-deficient individuals. J Clin Invest 77, 1952-1961.

Mulgrew, A.T., Taggart, C.C., Lawless, M.W., Greene, C.M., Brantly, M.L., O'Neill, S.J. \& McElvaney, N.G. (2004). Z $\alpha_{1}$-antitrypsin polymerizes in the lung and acts as a neutrophil chemoattractant. Chest 125: 1952-1957.

Nukiwa, T., Satoh, K., Brantly, M.L., Ogushi, F., Fells, G.A., Courtney, M. \& Crystal, R.G. (1987). Identification of a second mutation in the protein-coding sequence of the $Z$ type alpha 1-antitrypsin gene. J Biol Chem 262, 11999-12004.

Oakeshott, J.G, Muir, A., Clark, P., Martin, N.G., Wilson, S.R. \& Whitfield, J.B. (1985). Effects of the protease inhibitor $(\mathrm{Pi})$ polymorphism on alpha-1-antitrypsin concentration and elastase inhibitory capacity in human serum. Ann Hum Biol 12, 149-160.

Ogushi, F., Hubbard, R.C., Vogelmeier, C., Fells, G.A. \& Crystal. R.G. (1991). Risk factors for emphysema. Cigarette smoking is associated with a reduction in the association rate constant of lung $\alpha 1$-antitrypsin for neutrophil elastase. J Clin Invest 87, 10601065 .

Ogushi, F., Fells, G.A., Hubbard, R.C., Straus, S.D. \& Crystal, R.G. (1987). Z-type $\alpha 1-$ antitrypsin is less competent then M1-type $\alpha 1$ - antitrypsin as an inhibitor of neutropfil elastase. J Clin Invest 80, 1366-1374. 
Olsen, G.N., Harris, J.O., Castle, J.R., Waldman, R.H. \& Karmgard, H.J. (1975). Alpha-1antitrypsin content in the serum, alveolar macrophages, and alveolar lavage fluid of smoking and nonsmoking normal subjects. J Clin Invest 55, 427-30

Owen, M.C., Brennan, S.O., Lewis, J.H. \& Carrell, R.W. (1983). Mutation of antitrypsin to antithrombin: $\alpha 1$-antitrypsin Pittsburgh (358 met $\rightarrow$ arg), a fatal bleeding disorder. New Eng J Med 309, 694-698.

Owen, M.C., Carrell, R.W. \& Brennan, S.O. (1976).The abnormality of the S variant of human $\alpha-1$-antitrypsin. Biochim Biophys Acta 453, 257-261.

Parfrey, H., Dafforn, T.R., Belorgey, D., Lomas, D.A. \& Mahadeva, R. (2004). Inhibiting polymerization: new therapeutic strategies for $\mathrm{Z} \quad \alpha_{1}$-antitrypsin-related emphysema. Am J Respir Cell Mol Biol 31, 133-139.

Parmar, J.S., Mahadeva, R., Reed, B.J., Farahi, N., Cadwallader, K.A., Keogan, M.T., Bilton, D., Chilvers, E.R. \& Lomas, D.A. (2002). Polymers of $\alpha_{1}$-antitrypsin are chemotactic for human neutrophils. A new paradigm for the pathogenesis of emphysema. Am J Respir Cell Mol Biol 26, 723-730.

Perlino, E., Cortese, R. \& Ciliberto, G. (1987). The human $\alpha_{1}$-antitrypsin gene is transcribed from two different promoters in macrophages and hepatocytes. EMBO J 6, 27672771.

Petrache, I., Fijalkowska, I., Medler, T.R., Skirball, J., Cruz, P., Zhen, L., Petrache, H.I., Flotte. T.R. \& Tuder, R.M. (2006a). $\alpha-1$ antitrypsin inhibits caspase-3 activity, preventing lung endothelial cell apoptosis. Am J Pathol 169, 1155-1166.

Petrache, I., Fijalkowska, I., Zhen, L., Medler, T.R., Brown, E., Cruz, P., Choe, K.H., Taraseviciene-Stewart, L., Scerbavicius, R., Shapiro, L., Zhang, B., Song, S., Hicklin, D., Voelkel, N.F., Flotte, T. \& Tuder, R.M. (2006b). A novel anti-apoptotic role for $\alpha_{1}$-antitrypsin in the prevention of pulmonary emphysema. Am J Respir Crit Care Med 173, 1222-1228.

Pott, G.B., Chan, E.D., Dinarello, C.A. \& Shapiro, L. (2009). $\alpha$-1-Antitrypsin is an endogenous inhibitor of proinflammatory cytokine production in whole blood. $J$ Leukoc Biol 85, 886-895.

Prins, J., van der Maijden, B.B., Kraaijenhagen, R.J. \& Wielders, J.P.M. (2008). Inherited chronic obstructive pulmonary disease: new selective-sequencing workup for $\alpha_{1}{ }^{-}$ antitrypsin deficiency identifies 2 previously unidentified Null alleles. Clin Chem 54, 101-107.

Pryor, W.A. (1997). Cigarette smoke radicals and the role of free radicals in chemical carcinogenicity. Environ Health Perspect 105, 875-882.

Pryor, W.A., Dooley, M.M. \& Church, D.F. (1984). Inactivation of human $\alpha$-1-proteinase inhibitor by gas-phase cigarette smoke. Biochem Biophys Res Commun 122, 676- 681.

Rahman, I. (2005). Oxidative stress in pathogenesis of chronic obstructive pulmonary disease: cellular and molecular mechanisms. Cell Biochem Biophys 43, 167-188.

Richards, C.D. \& Gauldie, B.B. (1991). Cytokine control of acute phase protein expression. Eur Cytokine Network 2, 89-98.

Rodriguez, F., Jardí, R., Costa, X., Cotrina, M., Galimany, R., Vidal, R. \& Miravitlles, M. (2002). Rapid screening for $\alpha_{1}$-antitrypsin deficiency in patients with chronic obstructive pulmonary disease using dried blood specimens. Am J Respir Crit Care Med 166, 814-817. 
Rouhani, F., Paone, G., Smith, N.K., Krein, P., Barnes, P. \& Mark, L. (2000). Lung neutrophil burden correlates with increased pro-inflammatory cytokines and decreased lung function in individuals with $\alpha_{1}$-antitrypsin deficiency. Chest 117, 250S- $251 S$.

Sahin, U., Unlü, M., Ozgüner, F., Sütcü, R., Akkaya, A. \& Delibas, N. (2001). Lipid peroxidation and glutathione peroxidase activity in chronic obstructive pulmonary disease exacerbation: prognostic value of malondialdehyde. J Basic Clin Physiol Pharmacol 12, 59-68.

Satoh, K., Nukiwa, T., Brantly, M., Garver Jr R.I., Hofker, M., Courtney, M. \& Crystal, R.G. (1988). Emphysema associated with complete absence of $\alpha 1$ - antitrypsin of a stop codon in an $\alpha 1$-antitrypsin-coding exon. Am J Hum Genet 42, 77-83.

Schroeder, W.T., Miller, M.F., Woo, S.L. \& Saunders, G.F. (1985). Chromosomal localization of the human $\alpha_{1}$-antitrypsin gene (PI) to 14q31-32. Am J Hum Genet, 37, 868-872.

Scott, L.J., Russell, G.I., Nixon, N.B., Dawes, P.T. \& Mattey, D.L. (1999). Oxidation of $\alpha_{1}{ }^{-}$ proteinase inhibitor by the myeloperoxidase-hydrogen peroxidase system promotes binding to immunoglobulin A. Biochem Biophys Res Commun 255, 562-567.

Seixas, S., Garcia, O., Trovoada, M.J., Santos, M.T., Amorim, A. \& Rocha, J. (2001). Patterns of haplotype diversity within the serpine gene cluster at 14q32.1: insights into the natural history of the $\alpha_{1}$-antitrypsin polymorphism. Hum Genet 108, 20-30.

Senn, O., Russi, E.W., Schindler, C., Imboden, M., von Eckardstein, A., Brändli, O., Zemp, E., Ackermann-Liebrich, U., Berger, W., Rochat, T., Luisetti, M. \& Probst-Hensch, N.M. (2008). Circulating alpha1-antitrypsin in the general population: determinants and association with lung function. Clin Chem 54, 1331-1338.

Sharafkhaneh, A., Hanania, N.A. \& Kim, V. (2008). Pathogenesis of emphysema: from the bench to the bedside. Proc Am Thorac Soc 5, 475-477.

Silverman, E.K., Pierce, J.A., Province, M.A., Rao, D.C. \& Campbell, E,J. (1989). Variability of pulmonary function in alpha-1-antitrypsin deficiency: clinical correlates. Ann Intern Med 111, 982-991.

Silverman, E.K., Province, M.A., Campbell, E.J., Pierce, J.A. \& Rao, D.C. (1990). Biochemical intermediates in alpha 1-antitrypsin deficiency: residual family resemblance for total alpha 1-antitrypsin, oxidized alpha 1-antitrypsin, and immunoglobulin E after adjustment for the effect of the Pi locus. Genet Epidemiol 7, 137-149.

Simsek, H., Pinar, A., Altinbas, A., Alp, A., Balaban, Y.H., Buyukasik, Y., Ozcebe, O., Hascelik, G., Gedikoglu, G. \& Tatar, G. (2011). Cutoff level to detect heterozygous $\alpha_{1}$-antitrypsin deficiency in Turkish population. J Clin Lab Anal 25, 296-299.

Snyder, M.S, Katzmann, J.A., Butz, M.L., Yang, P., Dawson, D.B., Halling, K.C., Highsmith, W.E. \& Thibodeau, S.N. (2006). Diagnosis of $\alpha$-1-antitrypsin deficiency: an algorithm of quantification, genotyping, and phenotyping. Clin Chem 52, 22362242.

Sohrab, S., Petrusca, D.N., Lockett, A.D., Schweitzer, K.S., Rush, N.I., Gu, Y., Kamocki, K., Garrison, J. \& Petrache, I. (2009). Mechanism of $\alpha-1$ antitrypsin endocytosis by lung endothelium. FASEB J 23, 3149-3158.

Sørheim, I.C., Bakke, P., Gulsvik, A., Pillai, S.G., Johannessen, A., Gaarder, P.I., Campbell, E.J., Agustí, A., Calverley, P.M., Donner, C.F., Make, B.J., Rennard, S.I., Vestbo, J., Wouters, E.F., Paré, P.D., Levy, R.D., Coxson, H.O., Lomas, D.A., Hersh, C.P. \& Silverman, E.K. (2010). $\alpha_{1}$-antitrypsin protease inhibitor MZ heterozygosity is asssociated with airflow obstruction in two large cohorts. Chest 138, 1125-1132. 
Stein, P.D., Leu, J.D., Welch, M.H. \& Guenter, C.A. (1971). Pathophysiology of the pulmonary circulation in emphysema associated with $\alpha 1$ antitrypsin deficiency. Circulation 43, 227-239.

Stockley, R.A. \& Burnett D. (1979). Alpha-1-antitrypsin and leucocyte elastase in infected and noninfected sputum. Am Rev Respir Dis 120, 1081-1086.

Stockley, R.A. (1984). Measurement of soluble proteins in lung secretions. Thorax 39, 241247.

Stoller JK, Smith P, Yang P. \& Spray, J. (1994). Physical and social impact of alpha-1 antitrypsin deficiency: results of a mail survey of the readership of a national newsletter. Cleve Clin J Med 61, 461-467.

Stoller, J.K., Sandhaus, R.A., Turino, G., Dickson, R., Rodgers, K. \& Strange, C. (2005a). Delay in diagnosis of $\alpha_{1}$-antitrypsin deficiency: a continuing problem. Chest 128, 1989-1994.

Stoller, J.K, Tomashefski, J.Jr, Crystal, R.G., Arroliga, A., Strange, C., Killian, D.N., Schluchter, M.D. \& Wiedemann, H.P. (2005b). Mortality in individuals with severe deficiency of $\alpha 1$-antitrypsin: findings from the National Heart, Lung, and Blood Institute Registry. Chest, 127, 1196-1204.

Summers, F.A., Morgan, P.E., Davies, M.J. \& Hawkins, C.L. (2008). Identification of plasma proteins that are susceptible to thiol oxidation by hypochlorous acid and $\mathrm{N}$ chloramines. Chem Res Toxicol 21, 1832-1840.

Sveger, T. (1976). Liver disease in $\alpha_{1}$-antitrypsin deficiency detected by screening of 200,000 infants. N Engl J Med 294, 1316-1321.

Taggart, C., Cervantes-Laurean, D., Kim, G., McElvaney, N.G., Wehr, N., Moss, J. \& Levine, R.L. (2000). Oxidation of either methionine 351 or methionine 358 in $\alpha_{1}$-antitrypsin causes loss of anti-neutrophil elastase activity. J Biol Chem 275, 27258-27265.

Takahashi, H. \& Crystal, R.G. (1990). $\alpha 1$-antitrypsin Nullisola di procida: an $\alpha 1$-antitrypsin deficiency allele caused by deletion of all $\alpha 1$-antitrypsin coding exons. Am J Hum Genet 47, 403-413.

Taliercio, R.M., Chatburn, R.L. \& Stoller, J.K. (2010). Knowledge of alpha-1 antitrypsin deficiency among internal medicine house officers and respiratory therapists: results of a survey. Respir Care 55, 322-327.

Talmud, P.J., Martin, S., Steiner, G., Flavell, D.M., Whitehouse, D.B., Nagl, S., Jackson, R., Taskinen, M.R., Frick, M.H., Nieminen, M.S., Kesaniemi, Y.A., Pasternack, A., Humphries, S.E. \& Syvanne, M. (2003). Progression of atherosclerosis is associated with variation in the $\alpha_{1}$-antitrypsin gene. Arterioscler Thromb Vasc Biol 23, 644-649.

Tanash, H.A., Nilsson, P.M., Nilsson, J.A. \& Piitulainen, E. (2008). Clinical course and prognosis of never-smokers with severe alpha-1-antitrypsin deficiency (PiZZ). Thorax 63, 1091-1095.

Tanash, H.A, Nilsson, P.M., Nilsson, J.A. \& Piitulainen. E. (2010). Survival in severe alpha-1antitrypsin deficiency (PiZZ). Respir Res 11, 44.

Tarjan, E., Magyar, P., Vaczi, Z., Lantos, A. \& Vaszar, L. (1994). Longitudinal lung function study in heterozygous PiMZ phenotype subjects. Eur Respir J 7, 2199-2204.

Theegarten, D., Teschler, H., Stamatis, G., Konietzko, N. \& Morgenroth, K. (1998). Pathologico-anatomical results in surgical lung volume reduction of advanced emphysema. Pneumologie 52, 702-706. 
Tobin, M.J., Cook, P.J.L. \& Hutchinson, D.C.S. (1983). Alpha ${ }_{1}$-antitrypsin deficiency: the c linical and physiological features of pulmonary emphysema in subjects homozygous for Pi type Z. A survey by the British Thoracic Association. Br J Dis Chest 77, 14-27.

Torres-Ramos, Y.D., García-Guillen, M.L., Olivares-Corichi, I.M. \& Hicks, J.J. (2009). Correlation of plasma protein carbonyls and C-reactive protein with GOLD stage progression in COPD patients. Open Respir Med J 3, 61-66.

Turino, G.M., Barker, A.F., Brantly, M.L., Cohen, A.B., Connelly, R.P., Crystal, R.G., Eden, E., Schluchter, M.D. \& Stoller, J.K. (1996).Clinical features of individuals with PI*SZ phenotype of $\alpha-1$ antitrypsin deficiency. Am J Respir Crit Care Med 154, 1718- 1725.

Ueda, U., Mashiba, S. \& Uchida, K. (2002). Evaluation of oxidized alpha-1-antitrypsin in blood as an oxidative stress marker using anti-oxidative $\alpha 1$-AT monoclonal antibody. Clin Chim Acta 317, 125-131.

Wallaert, B., Gressier, B., Aerts, C., Mizon, C., Voisin, C. \& Mizon, J. (1991). Oxidative inactivation of $\alpha_{1}$-proteinase inhibitor by alveolar macrophages from healthy smokers requires the presence of myeloperoxidase. Am J Respir Cell Mol Biol 5, 437444.

Vogt, W. (1995). Oxidation of methionyl residues in proteins: tools, targets, and reversal. Free Radic Biol Med 18, 93-105.

WHO Meeting on Alpha 1 -Antitrypsin Deficiency, Geneva, March 18-20, 1996.

Wood, A.M., Harrison, R.M., Semple, S., Ayres, J.G. \& Stockley, R.A. (2009). Outdoor air pollution is associated with disease severity in $\alpha_{1}$-antitrypsin deficiency. Eur Respir J 34, 346-353.

Woolhouse, I.S., Bayley, D.L. \& Stockley, R.A. (2002). Sputum chemotactic activity in chronic obstructive pulmonary disease: effect of $\alpha_{1}$-antitrypsin deficiency and the role of leukotriene B(4) and interleukin 8. Thorax 57, 709-714.

Yang, S.R., Chida, A.S., Bauter, M.R., Shafiq, N., Seweryniak, K., Maggirwar, S.B., Kilty, I. \& Rahman I. (2006). Cigarette smoke induces proinflammatory cytokine release by activation of NF-kappaB and posttranslational modifications of histone deacetylase in macrophages. Am J Physiol Lung Cell Mol Physiol 291, :L46-L57.

Yoshida, A., Ewing, C., Wessels, M., Lieberman, J. \& Gaidulis, L. (1977). Molecular abnormality of PI S variant of human alpha1-antitrypsin. Am J Hum Genet 29, 233239.

Yu, M.H., Lee, K.N. \& Kim, J. (1995). The Z type variation of human $\alpha_{1}$-antitrypsin causes a protein folding defect. Nature Structural Biol 2, 363-367.

Zorzetto, M., Russi, E., Senn, O., Imboden, M., Ferrarotti, I., Tinelli, C., Campo, I., Ottaviani, S., Scabini, R., von Eckardstein, A., Berger, W., Brändli, O., Rochat, T., Luisetti, M. \& Probst-Hensch, N. (2008). SERPINA1 gene variants in individuals from the general populationwith reduced $\alpha_{1}$-antitrypsin concentrations. Clin Chem 54, 13311338. 


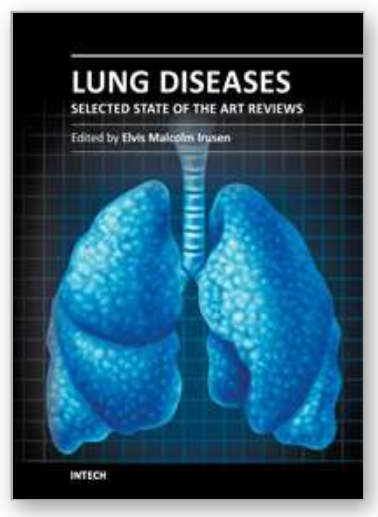

\section{Lung Diseases - Selected State of the Art Reviews}

Edited by Dr. Elvisegran Malcolm Irusen

ISBN 978-953-51-0180-2

Hard cover, 690 pages

Publisher InTech

Published online 02, March, 2012

Published in print edition March, 2012

The developments in molecular medicine are transforming respiratory medicine. Leading clinicians and scientists in the world have brought their knowledge and experience in their contributions to this book. Clinicians and researchers will learn about the most recent advances in a variety of lung diseases that will better enable them to understand respiratory disorders. This treatise presents state of the art essays on airways disease, neoplastic diseases, and pediatric respiratory conditions. Additionally, aspects of immune regulation, respiratory infections, acute lung injury/ARDS, pulmonary edema, functional evaluation in respiratory disorders, and a variety of other conditions are also discussed. The book will be invaluable to clinicians who keep up with the current concepts, improve their diagnostic skills, and understand potential new therapeutic applications in lung diseases, while scientists can contemplate a plethora of new research avenues for exploration.

\section{How to reference}

In order to correctly reference this scholarly work, feel free to copy and paste the following:

Aleksandra Topic and Dragica Radojkovic (2012). Polymerization and Oxidation of Alpha-1-Antitrypsin in Pathogenesis of Emphysema, Lung Diseases - Selected State of the Art Reviews, Dr. Elvisegran Malcolm Irusen (Ed.), ISBN: 978-953-51-0180-2, InTech, Available from: http://www.intechopen.com/books/lungdiseases-selected-state-of-the-art-reviews/polymerization-and-oxidation-of-alpha-1-antitrypsin-inpathogenesis-of-emphysema

\section{INTECH}

open science | open minds

\section{InTech Europe}

University Campus STeP Ri

Slavka Krautzeka 83/A

51000 Rijeka, Croatia

Phone: +385 (51) 770447

Fax: +385 (51) 686166

www.intechopen.com

\section{InTech China}

Unit 405, Office Block, Hotel Equatorial Shanghai

No.65, Yan An Road (West), Shanghai, 200040, China

中国上海市延安西路65号上海国际贵都大饭店办公楼 405 单元

Phone: +86-21-62489820

Fax: $+86-21-62489821$ 
(C) 2012 The Author(s). Licensee IntechOpen. This is an open access article distributed under the terms of the Creative Commons Attribution 3.0 License, which permits unrestricted use, distribution, and reproduction in any medium, provided the original work is properly cited. 